$$
\vdots:
$$





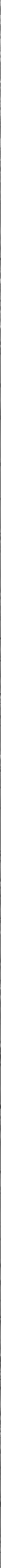




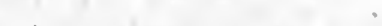

(is)

197.

sit

Q).

$120 x^{7}$

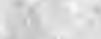

6

8

(a) 62,25 oring

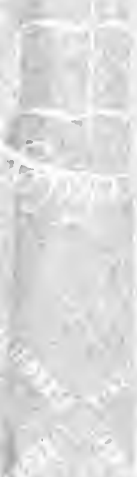

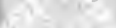





\section{THE MONROE DOCTRINE AFTER THE WAR *}

\section{By George Grafton Wilson,}

Professor of International Law, Harvard University.

The President of the United States on January 22, 1917, addressing the Senate, said, "perhaps I am the only person in high authority amongst all the people of the world who is at liberty to speak and hold nothing back," and proposed "that the nations should with one accord adopt the doctrine of President Monroe as the doctrine of the world." The President, referring to the propositions as to "the foundations of peace among the nations," also said, "I feel confident that I have said what the people of the United States would wish me to say;" and later in. the same address he asserted, "I would fain believe that I am speaking for the silent mass of mankind everywhere."

As President of the United States, Mr. Wilson's words may unquestionably and properly be regarded in foreign countries as expressing the policy of the United States Governmęnt. As the head of the Government of a neutral state occupying an important place in the world, when many other states were engaged in war, the claim to be speaking for the silent mass of mankind everywhere was not wholly presumption.

It can also certainly be claimed that a President of the United States in 1917 has an equal right with a President of the United States in 1823 to state what American policy is, and, if in 1917 the policy of 1823 is reaffirmed, then such policy would be worthy of even greater consideration in international affairs.

President Wilson on January 22, 1917, while proposing a concert of power, government by consent of the governed, freedom of

* See also address National Conference on Foreign Relations of the United States, held under auspices American Academy of Political Science, Long Beach, New York, May 30, 1917, in Proceedings of the Academy of Political Science in the City of New York, VIII, No. 2, 297-302. 
the seas, limitation of armament, and advocating "that the nations should with one accord adopt the doctrine of President Monroe as the doctrine of the world," explained that, under this world doctrine, "no nation should seek to extend its polity over any other nation or people, but that every people should be left free to determine its own polity, its own way of development, unhindered, unthreatened, unafraid, the little along with the great and powerful."

Clearly, this recently announced American policy would for the period after the war enlarge the scope and operation of the Monroe Doctrine. The realization of this fact is evident in foreign opinion. On January 24 Bonar Law, chancellor of the exchequer, in a speech at Bristol, England, said of the address of President Wilson, "what President Wilson is longing for, we are fighting for." On January 26 it was announced from Petrograd, that Russia "can gladly indorse President Wilson's communication." The part relating to the freedom of the seas found partic-

1 "I have sought this opportunity to address you because I thought that I owed it to you, as the council associated with me in the final determination of our international obligations, to disclose to you without reserve the thought and purpose that have been taking form in my mind in regard to the duty of our Government in the days to come when it will be necessary to lay afresh and upon a new plan the foundations of peace among the nations.

"It is inconceivable that the people of the United States should play no part in that great enterprise. To take part in such a service will be the opportunity for which they have sought to prepare themselves by the very principles and purposes of their polity and the approved practices of their Government ever since the days when they set up a new nation in the high and honorable hope that it might in all that it was and did show mankind the way to liberty. They cannot in honor withhold the service to which they are now about to be challenged. They do not wish to withhold it. But they owe it to themselves and to the other nations of the world to state the conditions under which they will feel free to render it.

"That service is nothing less than this, to add their authority and their power to the authority and force of other nations to guarantee peace and justice throughout the world. Such a settlement cannot now be long postponed. It is right that before it comes this Government should frankly formulate the conditions upon which it would feel justified in asking our people to approve its formal and solemn adherence to a League for Peace. I am here to attempt to state those conditions.

"The question upon which the whole future peace and policy of the world depends is this: Is the present war a struggle for a just and secure peace, or only for a new balance of power? If it be only a struggle for a new balance of power, who will guarantee, who can guarantee, the stable equilibrium of the new arrangement? Only a tranquil Europe can be a stable Europe. There must be, 
ular response in Russia." From other countries came statements that the ideals of the address were approved, but that the task involved was appalling, considering the condition of the world. As the United States has been the supporter of the Monroe Doctrine in the past, ${ }^{3}$ it must doubtless be its supporter after the

not a balance of power, but a community of power; not organized rivalries, but an organized common peace."-(Address of President Wilson, January 22, 1917.)

2 "So far as practicable, moreover, every great people now struggling towards a full development of its resources and of its powers should be assured a direct outlet to the great highways of the sea. Where this cannot be done by the cession of territory, it can no doubt be done by the neutralization of direct rights of way under the general guaranty which will assure the peace itself. With a right comity of arrangement no nation need be shut away from free access to the open paths of the world's commerce.

"And the paths of the sea must alike in law and in fact be free. The freedom of the seas is the sine qua non of peace, equality and co-operation. No doubt a somewhat radical reconsideration of many of the rules of international practice hitherto thought to be established may be necessary in order to make the seas indeed free and common in practically all circumstances for the use of mankind, but the motive for such changes is convincing and compelling. There can be no trust or intimacy between the peoples of the world without them. The free, constant, unthreatened intercourse of nations is an essential part of the process of peace and of development. It need not be difficult either to define or to secure the freedom of the seas if the governments of the world sincerely desire to come to an agreement concerning it."-(Address of President Wilson, January 22, 1917.)

3 "It is only when our rights are invaded or seriously menaced, that we resent injuries or make preparation for our defense. With the movements in this hemisphere we are, of necessity, more immediately connected, and by causes which must be obvious to all enlightened and impartial observers. The political system of the allied powers is essentially different in this respect from that of America. This difference proceeds from that which exists in their respective Governments. And to the defense of our own, which has been achieved by the loss of so much blood and treasure, and matured by the wisdom of their most enlightened citizens, and under which we have enjoyed unexampled felicity, this whole nation is devoted. We owe it, therefore, to candor and to the amicable relations existing between the United States and those powers to declare that we should consider any attempt on their part to extend their system to any portion of this hemisphere as dangerous to our peace and safety. With the existing colonies or dependencies of any European power we have not interfered and shall not interfere. But with the Governments who have declared their independence and maintained it, and whose independence we have, on great consideration and on just principles, acknowledged, we could not view any interposition for the purpose of oppressing them, or controlling in any other manner their destiny, by any European power, in any other light than as the manifestation of an unfriendly disposition toward the United States.

"Our policy in regard to Europe, which was adopted at an early stage of the wars which have so long agitated that quarter of the globe, nevertheless remains the same, which is, not to interfere in the internal concerns of any of its powers; 
war. It would be reasonable to conclude that the President, speaking on January 22, I9I7, was speaking of the probable attitude of the Government of the United States toward the doctrine. The principles of the doctrine would therefore be involved in the American ideas for the settlement of world difficulties. After a test of nearly one hundred years it is but a natural tendency that the doctrine should cease to be narrowly American and should have a world basis. If it means merely that each state should be allowed unhampered opportunity for development and that "good faith and justice toward all nations" should prevail, such an ideal would meet little formal opposition." If it means that the United States should be recognized as controlling the destinies of the American continents there would doubtless be opposition.

to consider the government de facto as the legitimate government for us; to cultivate friendly relations with it, and to preserve those relations by a frank, firm and manly policy; meeting, in all instances, the just claims of every power, submitting to injuries from none. But in rezard to these continents, circumstances are eminently and conspicuously different. It is impossible that the allied powers should extend their political system to any portion of either continent without endangering our peace and happiness; nor can anyone believe that our southern brethren, if left to themselves, would adopt it of their own accord. It is equally impossible, therefore, that we should behold such interposition, in any form, with indifference."-(Message of President Monroe, December 2, 1823.)

For full statement see Appendix, pages 286-287.

"Observe good faith and justice towards all nations. Cultivate peace and harmony with all. Religion and morality enjoin this conduct; and can it be that good policy does not equally enjoin it? It will be worthy of a free, enlightened, and at no distant period, a great nation to give to mankind the magnanimous and too novel example of a people always guided by an exalted justice and benevolence. Who can doubt that in the course of time and things the fruits of such a plan would richly repay any temporary advantages which might be lost by a steady adherence to it? Can it be that Providence has not connected the permanent felicity of a nation with its virtue? The experiment, at least, is recommended by every sentiment which ennobles human nature. Alas! is it rendered impossible by its vices?"-(Washington's Farewell Address, September I7, I796.)

- In r895 Secretary of State Olney said:

"Is it true, then, that the safety and welfare of the United States are so concerned with the maintenance of the independence of every American state as against any European power as to justify and require the interposition of the United States whenever that independence is endangered? The question can be candidly answered in but one way. The States of America, South as well as North, by geographical proximity, by natural sympathy, by similarity of governmental constitutions, are friends and allies, commercially and politically of the United States. To allow the subiugation of any of them by an European power is, of course, to completely reverse that situation and signifies the loss of all the advantages incident to their natural relations to us. But that is not all. The 
Even if expanded into the doctrine of America for Americans or some form of Pan-Americanism ${ }^{\circ}$ there might be question of worldwide approval. The doctrine may therefore be passing even now to a wider field of influence.

people of the United States have a vital interest in the cause of popular selfgovernment. They have secured the right for themselves and their posterity at the cost of infinite blood and treasure. They have realized and exemplified its beneficent operation by a career unexampled in point of natural greatness or individual felicity. They believe it to be for the healing. of all nations, and that civilization must either advance or retrograde accordingly as its supremacy is extended or curtailed. Imbued with these sentiments, the people of the United States might not impossibly be wrought up to an active propaganda in favor of a cause so highly valued both for themselves and for mankind. But the age of the Crusades has passed, and they are content with such assertion and defense of the right of popular self-government as their own security and welfare demand. It is in that view more than in any other that they believe it not to be tolerated that the political control of an American state shall be forcibly assumed by an European power."-(Olney to Ambassador Bayard, July 20, 1895, Moore, Digest of International Law, VI, 552-553.)

President Roosevelt in 1904 declared:

"Our interests and those of our southern neighbors are in reality identical. They have great natural riches, and if within their borders the reign of law and justice obtains, prosperity is sure to come to them. While they thus obey the primary laws of civilized society they may rest assured that they will be treated by us in a spirit of cordial and helpful sympathy. We would interfere with them only in the last resort, and then only if it became evident that their inability or unwillingness to do justice at home and abroad had violated the rights of the United States or had invited foreign aggression to the detriment of the entire body of American nations. It is a mere truism to say that every nation, whether in America or anywhere else, which desires to maintain its freedom, its independence, must ultimately realize that the right of such independence cannot be separated from the responsibility of making good use of it."-(Annual Message, December 6, 1904.)

For other passages from this message see Appendix, pages 296-297.

- Secretary of State Hay in rgor made the following statement:

"As respects controversies between the states of this hemisphere, the attitude of the United States has been repeatedly made clear. We wish to maintain equally friendly and close relations with all. We deplore any dissidences among them which may embarrass their common advancement. Our precept and example are before them to induce harmony and good will in all their mutual relations, but always in the line of the most absolute impartiality. While our good offices are at any time cheerfully at the disposal of our fellow republics to aid in composing their disputes, we hold that it is not our province to interfere in the adjustment of any questions involving their sovereign rights in their relations to one another. Although we may and do deeply regret whatever causes of division may arise between them, we abstain from forming a judgment on the merits of the difference, or espousing the cause of any one state against another, for to do so would impair the frank impartiality with which we stand ready to lend our friendly assistance toward a settlement whenever we have assurance that our counsels or our services will be acceptable to the parties concerned. 
It should be said, however, that the United States is no longer sole arbiter as to the interpretation of the Monroe Doctrine, as it once was, because under a large number of conventions this Government has agreed to refer differences even when relating to the Monroe Doctrine to investigation by a commission.' Indeed,

"The Government of the United States has on many occasions expressed its strong desire that peace and harmony shall prevail among the countries with which it holds friendly relations, and especially among the republics of the American continents whose systems of government rest upon a common basis, and whose material interests are intimate and interdependent. It has taken several favorable opportunities to advocate the resort to arbitration in settlement of diffculties not adjustable in the ordinary channels of intercourse, and has itself set an example by recurring to this humane and intelligent international forum. In one notable instance its counsels and offices were lent to bring about the arbitration of a boundary dispute between a Spanish-American state and a European power, doing so in furtherance of the national policy announced nearly eighty years ago."-(The Secretary of State to the Chilean Minister, January 3, I90I, Moore, Digest of International Law, VI, 603-604.)

'The general form of these agreements follows:

The United States of America and the Republic of Salvador, being desirous to strengthen the bonds of amity that bind them together and also to advance the cause of general peace, have resolved to enter into a treaty for that purpose and to that end have appointed as their plenipotentiaries:

The President of the United States, the Honorable William Jennings Bryan, Secretary of State; and

The President of Salvador, Señor Don Federico Mejía, Envoy Extraordinary and Minister Plenipotentiary of Salvador to the United States;

Who, after having communicated to each other their respective full powers, found to be in proper form, have agreed upon the following articles:

ART. I. The high contracting parties agree that all disputes between them, of every nature whatsoever, which diplomacy shall fail to adjust, shall be submitted for investigation and report to an International Commission, to be constituted in the manner prescribed in the next succeeding Article; and they agree not to declare war or begin hostilities during such investigation and report.

ART. II. The International Commission shall be composed of five members, to be appointed as follows: One member shall be chosen from each country, by the Government thereof; one member shall be chosen by each Government from some third country; the fifth member shall be chosen by common agreement between the two Governments. The expenses of the Commission shall be paid by the two Governments in equal proportion.

The International Commission shall be appointed within four months after the exchange of the ratifications of this treaty; and vacancies shall be filled according to the manner of the original appointment.

ART. III. In case the high contracting parties shall have failed to adjust a dispute by diplomatic methods, they shall at once refer it to the International Commission for investigation and report. The International Commission may, however, act upon its own initiative, and in such case it shall notify both Governments and request their co-operation in the investigation.

The report of the International Commission shall be completed within one year after the date on which it shall declare its investigation to have begun, unless the high contracting parties shall extend the time by mutual agreement. 
under these treaties disputes of every nature whatsoever are to be referred to a commission. Such treaties are operative with nearly all the great states except Germany and Japan, and with most of the smaller powers.

Again, it may be said that it is to be presumed that these treaties were made to be observed. The commissions established or to be established in accordance with the terms of these treaties are international rather than American. Therefore, under the treaties by which the United States is already bound and has been bound since I9I3, the Monroe Doctrine, if the subject of a difference with a treaty power, must be referred to an international commission. For the parts of the world now under these treaties the doctrine has had since 1913 something of the aspect which President Wilson's address may be forecasting for an area much larger than the Americas.

Of these treaties there are in fact now ratified twenty or more, and about half as many more have been negotiated. If thus for half the states of the world the Monroe Doctrine may now be subjected ta international standards of judgment, its purely national and American character may be said already to have been waived. The next step-the recognition by the world of the general principles underlying the doctrine as likewise sound for world policy-would not now be a long step for the United States.

When the Monroe Doctrine was originally published in Europe it met with approval from liberal statesmen, who hailed it as shed-

The report shall be prepared in triplicate; one copy shall be presented to each Government, and the third retained by the Commission for its files.

The high contracting parties reserve the right to act independently on the subject-matter of the dispute after the report of the Commission shall have been submitted.

ART. IV. Pending the investigation and report of the International Commission, the high contracting parties agree not to increase their military or naval programs, unless danger from a third power should compel such increase, in which case the party feeling itself menaced shall confidentially communicate the fact in writing to the other contracting party, whereupon the latter shall also be released from its obligation to maintain its military and naval status quo.

ART. V. The present treaty shall be ratified by the President of the United States of America, by and with the advice and consent of the Senate thereof; and by the President of the Republic of Salvador, with the approval of the Congress thereof; and the ratifications shall be exchanged as soon as possible. 
ding "joy, exultation, and gratitude over all free men in Europe." The reactionary Metternich, "who hated all constitutions," maintained that it was a natural consequence following the establishment of free states, and "that great calamities would be brought upon Europe by the establishment of these vast republics in the New World." Later, Bismarck regarded it as a piece of "international impertinence." At home the propositions of Monroe had been received with a degree of proud self-satisfaction.' By many it was regarded as giving to the Declaration of Independence a wider scope.

Many other interpretations followed, and these were frequently adapted to temporary policies, but the doctrine was always regarded as a special American contribution toward the wellbeing of the western continent.

It shall take effect immediately after the exchange of ratifications, and shall continue in force for a period of five years; and it shall thereafter remain in force until twelve months after one of the high contracting parties shall have given notice to the other of an intention to terminate it.

In witness whereof the respective plenipotentiaries have signed the present treaty and have affixed thereunto their seals.

Done in Washington on the seventh day of August, in the year of our Lord nineteen hundred and thirteen.

8 "The question with regard to Spanish America is now, I believe, disposed of, or nearly so; for an event has recently happened than which none has ever dispersed greater joy, exultation and gratitude over all the free men of Europe; that event, which is decisive on the subject, is the language held with respect to Spanish America in the message of the President of the United States."-(Henry Brougham, the English statesman, cited in Moore, Digest of International Law, VI, 4II.)

- Secretary Olney, reviewing the attitude on the doctrine, said in 1895:

"Its pronouncement by the Monroe administration at that particular time was unquestionably due to the inspiration of Great Britain, who at once gave to it an open and unqualified adhesion which has never been withdrawn. But the rule was decided upon and formulated by the Monroe administration as a distinctively American doctrine of great import to the safety and welfare of the United States after the most careful consideration by a Cabinet which numbered among its members John Quincy Adams, Calhoun, Crawford and Wirt, and which before acting took both Jefferson and Madison into its counsels. Its promulgation was received with acclaim by the entire people of the country irrespective of party. Three years after, Webster declared that the doctrine involved the honor of the country. 'I look upon it,' he said, ' as part of its treasures of reputation, and for one I intend to guard it,' and he added,

"I I look on the message of December, 1823 , as forming a bright page in our history. I will help neither to erase it nor to tear it out; nor shall it be by any act of mine blurred or blotted. It did honor to the sagacity of the Government, and I will not diminish that honor.' "-(Olney to Ambassador Bayard, Moore, Digest of International Law, VI, 549.) 
It is now proposed by President Wilson not that no European nation should seek to extend its authority over an American nation but "that no nation should seek to extend its polity over any other nation or people."

The reason for the early acceptance of the Monroe Doctrine was the physical power of the United States and the remoteness geographically of the area to which the doctrine applied. President Cleveland in his special message of December $17,1895,{ }^{10}$ stated that the doctrine "cannot become obsolete while our republic endures" and that it found its basis in "the theory that every nation shall have its rights protected and its just claims enforced." Secretary of State Olney at the same period pointed out to Great Britain that "the people of the United States have a vital interest in the cause of popular self-government" and that the British policy in reference to the Venezuelan boundary was so threatening to American policy and rights that his Government could not permit, "if the power of the United States is adequate," the accomplishment of the British ends. There is thus involved, if the Monroe doctrine is to be maintained, the existence of a power behind it which will insure respect.

In a sense the Monroe Doctrine aimed in 1823 to make the western hemisphere "safe for democracy." The President's war message of April 2, 1917, said: "The world must be made safe for democracy." In this broad conception the United States may thus be said to be fighting for a Monroe Doctrine for the world. Experience has shown that the western hemisphere has not been "safe for democracy" at all times and that the United States has had to be ready to use force to maintain the rights of self-governing nations." Accordingly in the same message and else-

\section{${ }^{10}$ See Appendix, pages 293-294.}

11 In his message of December 3, 1901, President Roosevelt said:

"Just 78 years have passed since President Monroe in his annual message announced that 'the American continents are henceforth not to be considered as subjects for future colonization by any European power.' In other words, the Monroe doctrine is a declaration that there must be no territorial aggrandizement by any non-American power at the expense of any American power or American soil. It is in no wise intended as hostile to any nation in the Old World. Still less is it intended to give cover to any aggression by one New World power at the expense of any other. It is simply a step, and a long step, toward assuring the 


\section{where President Wilson has expressed the conviction that there} must be "a partnership of democratic nations" to maintain their institutions. ${ }^{12}$ This idea had already received general acceptance among the leading nations of the world ${ }^{13}$ and has been more and more generally approved as the war has dragged from weeks into months and from months into years.

universal peace of the world by securing the possibility of permanent peace on this hemisphere.

"During the past century other influences have established the permanence and independence of the smaller states of Europe. Through the Monroe Doctrine we hope to be able to safeguard like independence and secure like permanence for the lesser among the New World nations."

For other passages from this message see Appendix, pages 295-296.

12 " I am speaking as an individual, and yet I am speaking also, of course, as the responsible head of a great government, and I feel confident that I have said what the people of the United States would wish me to say. May I not add that I hope and believe that I am in effect speaking for liberals and friends of humanity in every nation and of every program of liberty? I would fain believe that I am speaking for the silent mass of mankind everywhere who have as yet had no place or opportunity to speak their real hearts out concerning the death and ruin they see to have come already upon the persons and the homes they hold most dear.

"And in holding out the expectation that the people and Government of the United States will join the other civilized nations of the world in guaranteeing the permanence of peace upon such terms as I have named I speak with the greater boldness and confidence because it is clear to every man who can think that there is in this promise no breach in either our traditions or our policy as a nation, but a fulfilment, rather, of all that we have professed or striven for.

"I am proposing, as it were, that the nations should with one accord adopt the doctrine of President Monroe as the doctrine of the world: that no nation should seek to extend its polity over any other nation or people, but that every people should be left free to determine its own polity, its own way of development, unhindered, unthreatened, unafraid, the little along with the great and powerful.

"I am proposing that all nations henceforth avoid entangling alliances which would draw them into competitions of power, catch them in a net of intrigue and selfish rivalry, and disturb their own affairs with influences intruded from without. There is no entangling alliance in a concert of power. When all unite to act in the same sense and with the same purpose all act in the common interest and are free to live their own lives under a common protection.

"I am proposing government by the consent of the governed; that freedom of the seas which in international conference after conference representatives of the United States have urged with the eloquence of those who are the convinced disciples of liberty; and that moderation of armaments which makes of armies and navies a power for order merely, not an instrument of aggression or of selfish violence. "These are American principles, American policies. We could stand for no others. And they are also the principles and policies of forward looking men and women everywhere, of every modern nation, of every enlightened community. They are the principles of mankind and must prevail." - (President Wilson, Address to the Senate, January 22, 1917.)

13 "President Wilson's aim is to have peace now and security for peace in the future. That is our aim, and it is our only aim. He hopes to secure this by 
President Wilson in his war message to Congress on April 2, 1917, stating that his mind had not changed since January 22, said:

Our object now, as then, is to vindicate the principles of peace and justice in the life of the world as against selfish autocratic power and to set up amongst the really free and self-governed peoples of the world such a concert of purpose and of action as will henceforth insure the observance of those principles.

Monroe, looking to the political system of central Europe in I823, had taken a similar position, saying of the attitude of the powers belonging to the so-called Holy Alliance that it was impossible that they "should extend their political system to any portion of either [American] continent without endangering our peace and happiness; nor can any one believe that our southern brethren, if left to themselves, would adopt it of their own accord."

It is evident now that the United States does not desire to maintain alone the principles of such a doctrine as that enunciated by Monroe, for President Wilson in his address to Congress on April 2, 1917, said:

A steadfast concert for peace can never be maintained except by a partnership of democratic nations. No autocratic government could be trusted to keep faith within it or observe its covenants. It must be a league of honor, a partnership of opinion. Intrigue would eat its vitals away; the plottings of inner circles who could plan what they would and render account to no one would be a corruption seated at its very heart. Only free peoples can hold their purpose and their honor steady to a common end and prefer the interests of mankind to any narrow interest of their own.

means of a league of peace among the nations, and he not only spoke in favor of such a league but he is trying to induce the American Senate to take the steps necessary to give effect to it. It would not be right to regard this proposal as something altogether Utopian. You know that almost up to our own day dueling continued, and just as the settling of private disputes by the sword has now become unthinkable, so, I think, we may hope that the time will come when all the nations of the world will play the part which Cromwell described as his life work - to act as constable and keep peace. That time will come, I hope. . . .

"Our aim is the same as President Wilson's. What he is longing for we are fighting for. Our sons and brothers are dying for it, and we mean to secure it. The heart of the people of this country is longing for peace. We are praying for peace, a peace which will bring back in safety those who are dear to us, but a peace which will mean this-that those who will never come back shall not have laid down their lives in vain."-(Andrew Bonar Law, Chancellor of the Exchequer, January $24,1917$. 
Certainly some kind of league will be needed if the principles of the Monroe Doctrine are to receive general respect. There is developing a growing opinion favorable to a sanction for international security and peace through co-operation or joint action of some kind. Whether this sanction be furnished by a league to enforce peace ${ }^{14}$ or by some other guaranty, it is certain that the world seems weary of the old system under which any ruler might, if he decided it to be for his interest, disturb the peace of the world and subdue weaker peoples. Monroe in 1823 had said of the then weaker states to the south of the United States that this Government would view as "the manifestation of an unfriendly disposition toward the United States . . . any interposition for the purpose of oppressing them, or controlling in any other manner their destiny." These states were at that time democracies and they were small and weak. The United States placed behind them the considerable power which the nation at that time wielded, and the democratic form of government has prevailed

${ }^{14}$ The program of the League to Enforce Peace is as follows:

"We believe it to be desirable for the United States to join a league of nations binding the signatories to the following:

"First: All justiciable questions arising between the signatory powers, not settled by negotiation, shall, subject to the limitations of treaties, be submitted to a judicial tribunal for hearing and judgment, both upon the merits and upon any issue as to its jurisdiction of the question.

"Second: All other questions arising between the signatories, and not settled by negotiation, shall be submitted to a council of conciliation for hearing, consideration and recommendation.

"Third: The signatory powers shall jointly use forthwith both their economic and military forces against any one of their number that goes to war, or commits acts of hostility, against another of the signatories before any question arising shall be submitted as provided in the foregoing.

"The following interpretation of Article Three has been authorized by the Executive Committee:

"'The signatory powers shall jointly employ diplomatic and economic pressure against any one of their number that threatens war against a fellow signatory without having first submitted its dispute for international inquiry, conciliation, arbitration or judicial hearing, and awaited a conclusion, or without having in good faith offered so to submit it. They shall follow this forthwith by the joint use of their military forces against that nation if it actually goes to war, or commits acts of hostility, against another of the signatories before any question arising shall be dealt with as provided in the foregoing.'

"Fourth: Conferences between the signatory powers shall be held from time to time to formulate and codify rules of international law, which, unless some signatory shall signify its dissent within a stated period, shall thereafter govern in the decisions of the Judicial Tribunal mentioned in Article One." 
upon the western continents. The United States, by treaty agreement putting the Monroe Doctrine to the test of fair international opinion, has in recent years in many treaties shown its willingness to justify the doctrine upon its merits.

Now with broader policy the United States proposes that after the war the powers of the world unite to guarantee for the larger area what it has guaranteed for the Americas-that democracy shall have an opportunity to develop without foreign intervention. The acceptance of this idea by the states of the world is not yet certain.

The American argument is not difficult, however. If it is good for the Americas that states and peoples should have complete freedom for self-realization, it is likewise good for the other states of the world. Of this belief the United States and other American states are now giving proof by action. While such a doctrine may imperil thrones, it builds up peoples, and for its extension even hostilities may be justified, as has been officially asserted:

We shall fight for the things we have always carried nearest our hearts, for democracy, for the right of those who submit to authority to have a voice in their own governments, for the rights and liberties of small nations, for a universal dominion of right by such a concert of free peoples as shall bring peace and safety to all nations and make the world itself at last free.

The United States cannot under such principles claim isolation as a justification for its policies, but the Monroe Doctrine, if it is to survive after the war, must rest upon the broader support which its fundamental character merits. It is possible that in its narrower interpretation as applied to the Americas because of their "free and independent condition" the Monroe Doctrine may still be maintained after the war, but it is to be hoped that under the broader scope of the principles of the doctrine, through a concert of the nations life, liberty and the pursuit of happiness may be permanently secure under governments deriving their just powers from the consent of the governed. 


\section{APPENDIX.}

The following summary of historical events and collection of documents has been prepared to accompany Professor Wilson's paper and is intended to elucidate the political situation which called forth the original Monroe Doctrine and to afford material for a broad comparison of that situation with the present one, which has called forth President Wilson's declaration respecting a Monroe doctrine for the world.

The texts of the original message of President Monroe, of explanatory or expansive statements by subsequent Presidents and other public documents of the United States which relate to the subject matter of the doctrine are also printed.

\section{The European Background of the Monroe Doctrine.}

The European rulers opposed to Napoleon objected to him because to them he represented the French Revolution and its ideas. The established rulers were by no means reconciled to his assumption of imperial powers for, though it was a tacit tribute to their status in the world, it involved admitting a parvenu to their circle and was followed by Napoleon's setting up many plebeians on thrones. These circumstances deeply grieved hereditary royalty, which considered the conditions an affront against their divine right to rule. It was inevitable that, after Napoleon's abdication on April 6, I8I4, they should combine to restore the "legitimate" ruler in the person of a Bourbon, Louis XVIII.

The powers who had accomplished the overthrow of Napoleon might perhaps have left the principle of legitimacy there had it not been for their desire to assure that France should be removed from the hegemony of Europe, which she had held for nearly two centuries. Accordingly they prepared to make certain of the future impotence of France by excluding her from any important part in the Congress of Vienna. By a protocol of September 22, 
I8I4, they agreed that, "as France has adopted a legitimate government," she would not be banished completely from the discussions, but that she "ought to be satisfied" with being "admitted only when the other parties are already of one mind." 1

France was aware of this intention and the instructions to Prince Talleyrand, the principal French delegate to the Congress of Vienna, were drawn up with a view to protecting French interests, prestige and future influence to the greatest extent possible, especially on the basis of the balance of power. These instructions ${ }^{2}$ had a single refrain, "legitimacy," expressed in the terms of the recognized legal term of sovereignty, by which, however, was to be understood for the purpose the fee-simple rights of "sovereigns" over the territory they ruled. The development of this principle in Europe during the next decade was the circumstance that called forth the Monroe Doctrine, for it underlay the Holy Alliance, whose activities made the pronouncement of the American President an act of statesmanship.

The religiously mystical influences that gave the Holy Alliance its textual form might have rendered it beneficent, but the principle of legitimacy on which the treaty of Vienna was based insured the opposite effect. The following quotations from Talleyrand's letters to Louis XVIII indicate the extent to which the settlement of 1815 was founded upon the theory which France adduced for her own diplomatic defense:

March 14, 1815: The principles of legitimacy, which had to be drawn from beneath the ruins under which the overthrow of so many ancient and the establishment of so many new dynasties had, as it were, buried them, which were accepted so coldly by some and rejected by others when we first produced them, have at last become appreciated. Your firmness in supporting them has not been without its effect. The whole honor of it belongs to your Majesty, and the unanimity with which the powers have pronounced against Bonaparte's last attempt is entirely due to it. ${ }^{3}$

${ }^{1}$ Georges Pallain, The Correspondence of Prince Talleyrand and King Louis XVIII, 405-406.

${ }^{2}$ Comte d'Angeberg (Leonard Boreyko Chodzko), Le Congrès de Vienne et les traités de $1815,215-238$. The instructions are dated September, 1814 .

${ }^{3}$ Pallain, op. cit., 393. 


\section{Report Presented to the King during his Journey from Ghent to Paris, June, I8I5.}

We showed that the principles of legitimacy must be held sacred in the interest of the people themselves, because legitimate governments can alone be strong and durable, whereas illegitimate governments, relying upon force only, fall to pieces the moment that support fails them, and then the people are delivered over to a succession of revolutions of which no one can foresee the end.

It took much time and trouble to get a hearing for these principles: They were too strict for the policy of some of the courts; they were contrary to the system adopted by the English in India, and probably inconvenient for Russia, who had certainly ignored them in several important and recent transactions; and before we succeeded in obtaining their recognition the Allied Powers had already made arrangements directly at variance with them....4

Their [the French delegates'] enlightened co-operation alone enabled me to overcome the many obstacles, to extinguish the ill feeling, and to remove the bad impressions with which I had to deal-enabled me, in a word, to restore to your Majesty's Government the influence which is justly its due in the councils of Europe. It was by determining to uphold the principle of legitimacy that we obtained this important result....5

The principle of legitimacy was also imperiled, and most seriously imperiled, by the foolish conduct of the defenders of legitimate power, who did not distinguish between the source of power and its exercise, and believed, or acted as if they believed, that legitimate power must necessarily be absolute and unquestioned.

However legitimate a power may be, its exercise nevertheless must vary according to the objects to which it is applied, and according to time and place. Now, the spirit of the present age in great civilized states demands that supreme authority shall not be exercised except with the concurrence of representatives chosen by the people subject to it. ... 6

It cannot be denied that, great as may be the advantages of legitimacy, it may nevertheless lead to abuses. This is felt strongly, because during the twenty years immediately preceding the Revolution the tendency of all political writing was to expose and exaggerate these abuses. Few persons know how to appreciate the advantages of legitimacy, because they are all in the future; but everybody is at once struck by its abuses,

$$
\text { 'Pallain, op. cit., 523. } \quad{ }^{5} \text { Ibid., } 538 . \quad \text { 'Ibid., } 540 .
$$


because they may occur at any moment and show themselves upon every occasion. Has any one during the last twenty years reflected enough to perceive that none but a legitimate government can be stable? A government that offers to every ambitious man the chance of upsetting it and placing another in its stead, lives a threatened life, and bears within itself a fermenting spirit of revolution, ready at any moment to break out. The notion unhappily prevails that legitimacy affords a sovereign too much facility for setting himself above all laws, by securing him in the possession of the throne, however ill he may govern. ${ }^{7}$

The Holy Alliance was signed at Paris September 26, I8I5, and received the limited approval of the British Prince Regent on October $6 .^{8} \quad$ It was published by the Tsar on the following Christmas day with a prefatory statement instinct with sounding religious sentiment. The documents which follow are the essential pronouncements of the Alliance and prove better than any comment the purposes of the allies.

\section{The Holy Alliance.}

In the name of the Most Holy and Indivisible Trinity.

Their Majesties the Emperor of Austria, the King of Prussia, and the Emperor of Russia, in consequence of the great events which have marked the course of the last three years in Europe, and especially of the blessings which it has pleased divine Providence to shower down upon those states which place their confidence and their hope in it alone, having acquired the intimate conviction of the necessity of settling the steps to be observed by the powers, in their reciprocal relations, upon the sublime truths which the holy religion of our Savior teaches;

${ }^{7}$ Pallain, op. cit., 541-542.

${ }^{8}$ France "acceded" to it November II, I815, apparently without the action being accepted.

The British letter stated:

"As the forms of the British constitution ... preclude me from acceding formally to this treaty, in the shape in which it has been presented to me, I adopt this course of conveying to the August Sovereigns who have signed it, my entire concurrence in the principles they have laid down, and in the declaration which they have set forth, of making the divine precepts of the Christian religion the invariable rule of their conduct in all their relations, social and political, and of cementing the union which ought ever to subsist between all Christian nations." (3 British and Foreign State Papers, 213.)

- Translated from 3 British and Foreign State Papers, 2I I-2I2. 
They solemnly declare that the present act has no other object than to publish, in the face of the whole world, their fixed resolution, both in the administration of their respective states, and in their political relations with every other Government, to take for their sole guide the precepts of that holy religion, namely, the precepts of justice, Christian charity and peace, which, far from being applicable only to private concerns must have an immediate influence upon the counsels of princes, and guide all their steps, as being the only means of consolidating human institutions and remedying their imperfections. In consequence, their Majesties have agreed on the following articles:

Art. I. Conformably to the words of the holy Scriptures which command all men to consider each other as brethren, the three contracting monarchs will remain united by the bonds of a true and indissoluble fraternity, and, considering each other as fellow-countrymen, they will, on all occasions and in all places, lend each other aid and assistance; and, regarding themselves toward their subjects and armies as fathers of families, they will lead them, in the same spirit of fraternity with which they are animated, to protect religion, peace and justice.

Art. II. In consequence, the sole principle in force, either between the said Governments or between their subjects, shall be that of doing each other reciprocal service, of testifying by unalterable goodwill the mutual affection which ought to animate them, of considering themselves all as members of one and the same Christian nation; for the three allied princes look on themselves as merely delegated by Providence to govern three branches of the one family, namely, Austria, Prussia and Russia, and thus confess that the Christian world, of which they and their people form a part, has in reality no other Sovereign than Him to whom alone power really belongs, because in Him alone are found all the treasures of love, science and infinite wisdom, that is to say, God, our divine Savior, the Word of the Most High, the Word of Life. Their Majesties consequently recommend, with the most tender solicitude for their peoples, as the sole means of enjoying that peace which arises from a gocd conscience and which alone is durable, to strengthen themselves every day more and more in the principles and exercise of the duties which the divine Savior has taught to mankind.

Art. III. All the powers who shall choose solemnly to avow the sacred principles which have dictated the present act, and shall acknowledge how important it is for the happiness of nations, too long agitated, that these truths should henceforth exercise over the destinies of mankind all 
the influence which belongs to them, will be received with equal ardor and affection into this holy alliance.

Done in triplicate and signed at Paris, the year of grace 1815 , the 14 th (26th) September.

Francis.

Frederick William.

Alexander.

\section{Declaration of the Five Cabinets, signed at Aix-la- Chapelle, November I5, I8I8.}

At the period of completing the pacification of Europe by the resolution of withdrawing the foreign troops from the French territory; and when there is an end of those measures of precaution which unfortunate circumstances had rendered necessary, the ministers and plenipotentiaries of their Majesties the Emperor of Austria, the King of France, the King of Great Britain, the King of Prussia and the Emperor of all the Russias have received orders from their sovereigns to make known to all the Courts of Europe, the results of their meeting at Aix-la-Chapelle, and with that view to publish the following declaration:

The convention of the 7 th of October, which definitively regulated the execution of the engagements agreed to in the treaty of peace of November $20,1815,{ }^{11}$ is considered by the sovereigns who concurred therein as the accomplishment of the work of peace and as the completion of the political system destined to insure its solidity.

The intimate union established among the monarchs, who are joint parties to the system, by their own principles no less than by the interests of their people offers to Europe the most sacred pledge of its future tranquility.

${ }^{10}$ No. VII in Convention ... for the evacuation of the French Territory. . . . (Parl. Pap. 1819, XVIII, 35I); Archives diplomatiques pour l'histoire du tems et des états, III, 526-527; Angeberg, op. cit., I760.

A protocol signed the same day declared the joint policy of the courts.

The political system known as that of the Holy Alliance had its origin in the treaty of Chaumont of March I, 1814 (I British and Foreign State Papers, I21129) and the treaty of Vienna of March 25, I815 (ibid., 2, 443). Its purely secular embodiment was the so-called quadruple alliance signed at Paris, November 20, 1815 (ibid., 3, 273-280).

11 The treaty referred to ended the military occupation of French territory:

"Art. I. The troops composing the army of occupation shall be withdrawn from the territory of France by the 3oth of November next, or sooner, if possible." 
The object of this union is as simple as it is great and salutary. It does not tend to any new political combination-to any change in the relations sanctioned by existing treaties. Calm and consistent in its proceedings, it has no other object than the maintenance of peace, and the guaranty of those transactions on which the peace was founded and consolidated.

The Sovereigns, in forming this august union, have regarded as its fundamental basis their invariable resolution never to depart, either among themselves or in their relations with other states, from the strictest observation of the principles of the right of nations; principles which, in their application to a state of permanent peace, can alone effectually guarantee the independence of each government and the stability of the general association.

Faithful to these principles, the Sovereigns will maintain them equally in those meetings at which they may be personally present, or in those which shall take place among their ministers; whether they be for the purpose of discussing in common their own interests or whether they shall relate to questions in which other governments shall formally claim that interference. The same spirit which will direct their councils and reign in their diplomatic communications will preside also at these meetings; and the repose of the world will be constantly their motive and their end.

It is with these sentiments that the Sovereigns have consummated the work to which they were called. They will not cease to labor for its confirmation and perfection. They solemnly acknowledge that their duties toward God and the people whom they govern make it peremptory for them to give to the world, as far as lies in their power, an example of justice, of concord and of moderation; happy in the power of consecrating, from henceforth, all their efforts to protect the arts of peace, to increase the internal prosperity of their states, and to awaken those sentiments of religion and morality whose influence has been but too much enfeebled by the misfortune of the times.

For Austria: Metternich.

France: Richelieu.

Great Britain: CAstlereagh.

Wellington.

Prussia: Hardenberg. BERNSTORFF.

Russia: Nesselrode.

Capo d'istria. 


\section{The Conferences of Troppau.}

\section{a. Circular of the Austrian, Prussian and Russian Missions to Foreign Courts. ${ }^{12}$}

Troppau, December 8, 1820.

Informed of the rumors, as extravagant as false, which the malevolence and the credulity of others have succeeded in spreading and caused to be believed on the object and results of the conferences of Troppau, the allied Courts have considered it necessary to furnish their respective missions in foreign countries authentic information so that they can be in a position to correct errors and suspicions which have been formed about them. The subjoined document is destined to fulfil this purpose. There is no question of making it the subject of any formal communication but there is nothing to prevent its being confidentially read. This same summary will be addressed to the ministers of —_ of —_. You will be good enough to concert with them on the precise use to make of it.

Inclosure: Short summary of the first results of the conferences of Troppau.

The events which took place March 8 in Spain, July 2 at Naples and the Portuguese catastrophe ${ }^{13}$ have necessarily given rise to a deep feeling

${ }^{12}$ Translated from 8 British and Foreign State Papers, II49-II5I; Archives diplomatiques pour l'histoire du tems et des états, I, 290-297; Comte d'Angeberg (Leonard Boreyko Chodzko), Le Congrès de Vienne et les traités de 1815, 1801. A meeting which did much to discourage liberal movements in Germany was held at Carlsbad August 6, 1819, resulting in the reactionary decrees of that date.

${ }^{13}$ The events referred to are:

On March 8, 1820, Ferdinand VII of Spain issued a rescript decreeing "that all persons who are imprisoned or arrested on account of political opinions, in any place in the kingdom whatsoever, should be set immediately at liberty. They may return to their homes, as may all those who for the same reason are abroad." March 9-17 he issued decrees establishing a cabinet, abolishing the inquisition, ordering constitutional elections for municipal authorities, granting freedom of the press and reorganizing the courts. (Archives diplomatiques, III, 107-119.)

On July 2, I820, a regiment stationed at Nola began a march to Naples under the banner of the Carbonari, a secret political society of liberal tenets. On July 7 Ferdinand I's son as viceregent ratified the Spanish constitution of 1812 for Naples. The conditions presented by the revolution were a formal oath to the constitution by the King, appointment of a junta to prepare its introduction and appointment of the revolutionary leader as commander-in-chief of the army. These terms were complied with on July 9.

On August 24, 1820, the city of Oporto, Portugal, rose and formed a provisional supreme junta to rule in the name of King John VI until the Cortes was convened. Lisbon did likewise and the two juntas convoked the Cortes to revise the Spanish constitution of 1812 to meet Portuguese needs. 
of uneasiness and chagrin in all those who are under the obligation of watching over the tranquility of states, but at the same time has made them recognize the need of reuniting and deliberating in common upon the methods of preventing all the evils which menace the foundations of Europe.

It was natural that these sentiments should make an especially keen impression upon the powers that had recently put down revolution and that had seen it again raise its head. It was not less natural that these powers, to combat it for the third time, should have recourse to the same methods of which they had made use with such success in that memorable struggle which delivered Europe from a yoke it had borne for 20 years.

Everything gave ground for hoping that this alliance, founded in the most critical circumstances, crowned with the most brilliant success, affirmed by the conventions of 1814,1815 and 1818 , at the same time that it prepared, established and affirmed the peace of the world and delivered the European continent from the military tyranny of the representative of the revolution, would also be in a position to put a check on a force not less tyrannical and less detestable, that of revolt and of crime.

Such were the motives and the purpose of the meeting at Troppau. The first are so evident that they require no development. The latter is so honorable and so salutary that the wishes of all good men undoubtedly will accompany the allied Courts in the noble combat they have just entered upon.

The enterprise, which imposes upon them the holiest engagements, is great and difficult; but a happy presentiment makes them hope that they will attain their purpose, invariably maintaining the spirit of those treaties to which Europe owes the peace and union existing among all its states.

The powers have exercised an incontestable right in commonly concerting measures of safety against the states in which an overturn of the government effected by revolt can only be considered as a dangerous example, which must have for a result an attitude hostile against all constitutions and legitimate governments. The exercise of this right of necessity became still more urgent when those in that situation sought to communicate to neighboring states the evil in which they themselves were plunged and to propagate revolt and confusion among them.

There is in this attitude and this conduct an evident rupture of the part which guarantees to all the Governments of Europe, besides the inviolability of their territory, the enjoyment of peaceable relations which exclude all reciprocal encroachment on their rights. 
This incontestable fact is the starting point for the allied Courts. The ministers who have been furnished at Troppau with positive instructions on the part of their Courts consequently concerted among themselves on the principles of conduct to follow toward states whose form of government had sustained violent attacks, and upon pacific or coercive measures which, in cases where it might have important effects and a salutary influence, might bring these states into the body of the alliance. The results of these deliberations have been communicated to the Courts of Paris and London in order that they can take them into consideration.

As the revolution of Naples daily takes deeper root, because nothing else exposes the tranquility of neighboring states to a danger so certain and so imminent and because it is not possible to act elsewhere so immediately and promptly, we are convinced of the necessity of proceeding against the kingdom of the Two Sicilies, in accordance with the principles declared above.

For the purpose of preparing measures of conciliation to this end, the Monarchs in session at Troppau invited the King of the Two Sicilies to meet with them at Laibach, a proceeding whose sole purpose was to free the will of his Majesty from all external constraint and to constitute this Monarch the mediator among his separated peoples and the states whose tranquility they threaten. The allied Monarchs being resolved not to recognize a government produced by open revolt, they can enter into negotiations only with the person of the King. Their ministers and agents at Naples have consequently received the necessary instructions....

b. Circular dispatch to his Majesty's missions to Foreign courts. ${ }^{14}$

Foreign OfFice,

Sir, January $2 \mathrm{I}, \mathrm{I} 82 \mathrm{I}$.

I should not have felt it necessary to have made any communication to you, in the present state of the discussions begun at Troppau and transferred to Laibach, had it not been for a circular communication

${ }^{14}$ Parl. Pap., I821, XXII, I; 8 British and Foreign State Papers, II60.

This dispatch was apparently published as the result of a Parliamentary discussion February 21, 1821 (Hansard, New Series, IV, 836-895), on a resolution of Sir James Mackintosh which read:

"That an humble address be presented to his Majesty, that he will be graciously pleased to give directions, that there be laid before this House, copies or 
which has been addressed by the Courts of Austria, Prussia and Russia to their several missions and which his Majesty's Government conceive, if not adverted to, might (however unintentionally) convey, upon the subject therein alluded to, very erroneous impressions of the past, as well as of the present, sentiments of the British Government.

It has become therefore necessary to inform you, that the King has felt himself obliged to decline becoming a party to the measures in question.

These measures embrace two distinct objects: Ist, The establishment of certain general principles for the regulation of the future political conduct of the allies in the cases therein described; $2 \mathrm{dly}$, The proposed mode of the dealing, under these principles, with the existing affairs of Naples.

The system of measures proposed under the former head, if to be reciprocally acted upon, would be in direct repugnance to the fundamental laws of this country. But even if this decisive objection did not exist, the British Government would nevertheless regard the principles on which these measures rest to be such as could not be safely admitted as a system of international law. They are of opinion that their adoption would inevitably sanction, and, in the hands of less beneficent Monarchs, might hereafter lead to, a much more frequent and extensive interference in the internal transactions of states, than they are persuaded is intended by the august parties from whom they proceed, or can be reconcilable either with the general interest, or with the efficient authority and dignity, of independent sovereigns. They do not regard the alliance as entitled, under existing treaties, to assume, in their character as allies, such general powers, nor do they conceive that such extraordinary powers could be assumed in virtue of any fresh diplomatic transaction among the allied Courts, without their either attributing to themselves a supremacy incompatible with the rights of other states, or, if to be acquired through the special accession of such states, without introducing a federative system in Europe, not only unwieldy and ineffectual to its object, but leading to many most serious inconveniences.

With respect to the particular case of Naples, the British Government, at the very earliest moment, did not hesitate to express their strong disapprobation of the mode and circumstances under which that revolution

extracts of such representations as have been made on the part of his Majesty's Government to the allied powers, respecting the interpretation given by them to the treaties subsisting between them and Great Britain, with reference to the right of general interference in the internal affairs of independent states, and respecting the measures proposed to be taken by them in the exercise of such right."

The resolution was lost by a majority of 69 ,-ayes I25, noes 194 . 
was understood to have been effected; but they, at the same time, expressly declared to the several allied Courts, that they should not consider themselves as either called upon, or justified, to advise any interference on the part of this country: They fully admitted however that other European states, and especially Austria and the Italian powers, might feel themselves differently circumstanced; and they professed that it was not their purpose to prejudge the question as it might affect them, or to interfere with the course which such states might think fit to adopt with a view to their own security, provided only that they were ready to give every reasonable assurance that their views were not directed to purposes of aggrandizement, subversive of the territorial system of Europe, as established by the late treaties.

Upon these principles, the conduct of his Majesty's Government with regard to the Neapolitan question has been, from the first moment, uniformly regulated, and copies of the successive instructions sent to the British authorities at Naples, for their guidance, have been, from time to time, transmitted for the information of the allied Governments.

With regard to the expectation, which is expressed in the circular above alluded to, of the assent of the Courts of London and Paris to the more general measures proposed for their adoption, founded, as it is alleged, upon existing treaties; in justification of its own consistency and good faith, the British Government, in withholding such assent, must protest against any such interpretation being put upon the treaties in question, as is therein assumed.

They have never understood these treaties to impose any such obligations; and they have, on various occasions, both in Parliament and in their intercourse with the allied Governments, distinctly maintained the negative of such a proposition: That they have acted with all possible explicitness upon this subject, would at once appear from reference to the deliberations at Paris in $\mathbf{I} 8 \mathbf{1 5}$, previous to the conclusion of the treaty of alliance;-at Aix-la-Chapelle in 1818;-and subsequently in certain discussions which took place in the course of the last year.

After having removed the misconception to which the passage of the circular in question, if passed over in silence, might give countenance; and having stated in general terms, without however entering into the argument, the dissent of his Majesty's Government from the general principle upon which the circular in question is founded, it should be clearly understood, that no Government can be more prepared than the British Government is, to uphold the right of any state or states to interfere, where their own immediate security or essential interests are 
seriously endangered by the internal transactions of another state. But as they regard the assumption of such right as only to be justified by the strongest necessity, and to be limited and regulated thereby, they cannot admit that this right can receive a general and indiscriminate application to all revolutionary movements, without reference to their immediate bearing upon some particular state or states, or be made prospectively the basis of an alliance. They regard its exercise as an exception to general principles, of the greatest value and importance, and as one that only properly grows out of the circumstances of the special case; but they at the same time consider that exceptions of this description never can, without the utmost danger, be so far reduced to rule, as to be incorporated into the ordinary diplomacy of states, or into the institutes of the law of nations.

As it appears that certain of the ministers of the three Courts have already communicated this circular dispatch to the Courts to which they are accredited, I leave it to your discretion to make corresponding communication on the part of your Government, regulating your language in conformity to the principles laid down in the present dispatch. You will take care, however, in making such communication, to do justice, in the name of your Government, to the purity of intention, which has no doubt actuated the august Courts in the adoption of the course of measures which they are pursuing. The difference of sentiment which prevails between them and the Court of London on this matter, you may declare, can make no alteration whatever in the cordiality and harmony of the alliance on any other subject, or abate their common zeal in giving the most complete effect to all their existing engagements.

I am, \&c.

Castlereagh.

\section{Declaration of the Ministers and Plenipotentiaries of the Emperors of Austria and Russia and of the King of Prussia by Order of their Monarchs at the Conclusion of the Conference of Laibach, May I2, I82 $1 .{ }^{15}$}

Europe knows the motives for the resolution taken by the allied Sovereigns to snuff out conspiracies and put an end to the troubles which

${ }^{15}$ Translated from Archives diplomatiques pour l'histoire du tems et des états, II, 390-397; 8 British and Foreign State Papers, I 20I; Angeberg, op. cit., I8I I. 
threaten the existence of this general peace, whose establishment has cost so much in effort and sacrifice.

At the very moment their generous resolution was accomplished in the Kingdom of Naples, a rebellion of a still more odious character-if that was possible-broke out in Piedmont. ${ }^{16}$

Neither the bonds which for so many centuries bound the reigning House of Savoy to its people nor the benefits of an enlightened administration, under a wise prince and paternal laws, nor the sad perspective of the evils to which the country had just been exposed were able to restrain the designs of the perverts.

The plan of a general overturn was traced. In this vast combination against the repose of nations, the conspirators of Piedmont had their assigned rôle. They were hastening to fulfil it.

The throne and the state have been betrayed, oaths violated, military honor contemned, and the forgetting of all duties has speedily brought the scourge of all disorders.

Everywhere the evil has presented the same character, everywhere a single spirit directed these baleful revolutions.

Not being able to find a plausible motive to justify them, nor national support to sustain them, it is in false doctrines that the authors of these overturns seek a defense, it is on criminal associations [Carbonari] that they found a more criminal hope. For them the salutary empire of laws is a yoke that it is necessary to break. They renounce the sentiments which inspire true love of country, and, putting in place of known duties the arbitrary and indefinite pretexts of a universal change in the constituted principles of society, they prepare calamities for the world without end.

The allied Sovereigns have recognized the dangers of this conspiracy in all their extent, but they have penetrated at the same time the real weakness of the conspirators through the veil of appearances and declamations. Experience has confirmed their presentiments. The resist-

${ }^{16}$ The Piedmontese army on March I0, 1821, declared that it "could not abandon the King to Austrian influence," which "impeded the good intentions of the Prince to satisfy his peoples, who desire to live under the reign of laws and to have their rights and interests assured by a liberal constitution." They looked to Victor Emmanuel to realize these intentions, in which case they would "defend the person of the King and the dignity of his crown against any enemy." Victor Emmanuel abdicated on March 13, Charles Albert of Savoy, Prince of Carignan, becoming regent on the same day and simultaneously promulgating the Spanish constitution of 1812. (Archives diplomatiques, II, 16-35.) With Austrian aid the ensuing revolution was ended on April IO-I I by the occupation of Turin and Alessandria. 
ance which legitimate authority has encountered has amounted to nothing, and the crime has disappeared before the sword of justice.

It is not to accidental causes, it is not even to the men who fared so badly on the day of combat that we can attribute the ease of such a success. It rests on a principle more consoling and more worthy of consideration.

Providence has struck terror to consciences so culpable, and the disapproval of the peoples, whose fate is compromised by the makers of trouble, has made the arms fall from their hands.

Solely intended to combat and to repress rebellion, the allied forces, far from supporting any interest of their own, have come to the aid of subjugated peoples, and the peoples have considered its employment as an aid in favor of their liberty and not as an attack against their independence. From that time war ceased; from that time the states which suffered the revolt have been no more than states friendly to the powers, which have never desired anything but their tranquility and their well being.

In the midst of these grave events and in a situation so delicate, the allied Sovereigns in accord with their Majesties the King of the Two Sicilies and the King of Sardinia have considered it indispensable to take the temporary measures of precaution indicated by prudence and prescribed by the common safety. The allied troops, whose presence was necessary for the re-establishment of order, have been stationed at suitable places, with the sole view to protecting the free exercise of legitimate authority and to aiding the preparation under this agis of the benefits which must efface the traces of evils so great.

The justice and disinterestedness which have presided over the deliberations of the allied Monarchs will always regulate their policy. In the future as in the past they will always have the purpose of preserving the independence and the rights of each state, as they are recognized and defined by existing treaties. The result of even a movement so dangerous will still be, under the auspices of Providence, the confirmation of the peace which the enemies of the peoples seek to destroy and the consolidation of an order of things which will assure to the nations their repose and their prosperity.

Penetrated by these sentiments, the allied Sovereigns in closing the conferences of Laibach have desired to announce to the world the principles which have guided them. They are determined never to recede from them, and all the friends of good will see and constantly find in their union an assured guaranty against the attempts of disturbers. 
It is with this purpose that their imperial and royal Majesties have ordered their plenipotentiaries to sign and publish the present declaration.

Laibach, May I2, I82I.

For Austria: MetTernich.

Baron von Vincent.

Prussia: Krusemarck.

Russia: Nesselrode.

CAPo d'Istrias.

Pozzo di Borgo.

5. Final Circular of the Congress of Verona Addressed by Order of the Three Sovereigns of Austria, Prussia and Russia, to their Legations Near Different Courts. ${ }^{17}$

Sir:

Verona, December I4, 1822.

You were informed by the documents sent to you on the closing of the conferences of Laibach in the month of May, 1821, that the reunion of the Monarchs and their cabinets would take place in the course of the year 1822 , and that they would then consider the term to be fixed to the measures which, on the proposals of the Courts of Naples and Turin, and with the consent of all the Courts of Italy, had been judged necessary to reaffirm the tranquility of the peninsula after the baleful events of the years 1820 and 1821 . This reunion has just taken place, and we are therefore going to inform you of its principal results.

After the convention signed at Novara on July $24,1821,{ }^{18}$ the occupation of a military line in Piedmont by a corps of auxiliary troops had been finally fixed to last a year, subject to examination by the reunion of 1822 , if the situation of the country should permit its cessation or render its extension necessary.... It has been recognized that the aid of an allied force was no longer necessary for maintaining the tranquility of Piedmont.... And it has been decreed by a new convention that the departure of these troops from Piedmont shall commence December 3I of this year and will be definitely ended by the transfer of the fortress of Alessandria on September 30, 1823 .

${ }^{17}$ Archives diplomatiques pour l'histoire du tems et des états, III, 538-544; Comte d'Angeberg (Leonard Boreyko Chodzko), Le Congrès de Vienne et les traités de 1815, 1817; Io British and Foreign State Papers, 921-925.

${ }^{18}$ Archives diplomatiques, II, 180-193. 
On the other hand, his Majesty the King of the Two Sicilies has declared to the three Courts participating in the convention signed at Naples October 18 that the actual state of his country would permit him to propose a reduction in the number of the auxiliary troops stationed in different parts of his kingdom. The allied Sovereigns have not hesitated to lend themselves to this proposal, and the army of occupation of the Kingdom of the Two Sicilies will be reduced to 17,000 men in the shortest possible time.

Thus is realized, to the extent that events have responded to the desires of the Monarchs, the declaration made at the close of the congress of Laibach: "That, far from wishing to prolong beyond the limits of a strict necessity their intervention in Italian affairs, their Majesties desired sincerely that the state of things which this painful duty imposed upon them should cease as soon as possible and would never occur again." Thus vanished the false alarms, the hostile interpretations, the sinister predictions which ignorance and bad faith had caused to resound through Europe in order to mislead the opinion of the peoples upon the frank and loyal intentions of the Monarchs. ...

The purpose of the Congress of Verona, as designed by a positive engagement, would have been fulfilled by the resolutions adopted for the relief of Italy. But the Sovereigns and Cabinets in assembly have not been able to refrain from regarding two serious complications whose development had constantly occupied them since the meeting of Laibach.

An event of great importance broke out toward the end of this last meeting. What the revolutionary spirit began in the western peninsula, what it tried in Italy, it has succeeded in accomplishing at the eastern extremity of Europe. At the time when the military revolts of Naples and Turin yielded to the approach of a regular force, the brand of insurrection was hurled into the midst of the Ottoman Empire [Greek revolution].... The Monarchs, determined on repulsing the principle of revolt in whatever place or under whatever form it might show itself, hastened to punish it with an equal and unanimous reproof. ...

Other events worthy of all solicitude on the part of the Monarchs have fixed their attention on the deplorable situation of the western peninsula of Europe. Spain undergoes the fate reserved for all countries which have the misfortune to seek good in ways which never lead to it. To-day it describes the fatal circle of its revolution, a revolution which deceived or perverted men pretend to represent as a benefit, even as the triumph of an enlightened century.... 
The legitimate power enchained and itself serving as the instrument for overturning all legal rights and liberties, all classes of the population in turmoil from the revolutionary movement, arbitrariness and oppression exercised under the forms of law, a kingdom delivered over to all kinds of convulsion and disorder, rich colonies justifying their emancipation by the same maxims on which the mother country has founded its public law, and which it tries in vain to condemn in another hemisphere, civil war consuming the last resources of the state-such is the picture which the actual situation in Spain presents to us....

\section{Europe's Attitude toward Spain and the Latin-American Revolution.}

The foreign ministers of Austria, Prussia and Russia between November 22 and December 14, 1822, during the Congress of Verona, sent notes to Spain indicating their agreement with the proposal that France should intervene in that country, where the "legitimate" ruler was a captive of the republican revolution. The tone of these notes is sufficiently illustrated by Metternich's remarks:

By the eternal decrees of Providence, good can never be secured for states any more than for individuals by forgetting the first duties imposed on man in the social order. ... Military revolt can never form the basis of a happy and durable government.

On December 25, I822, the French cabinet sent to Spain a note in which it was announced that France, "intimately united with her allies in the firm purpose of destroying by every means the revolutionary principles and movements," would take effective measures to protect herself-and her friends-from the contagion. The ensuing French invasion freed Ferdinand VII in September, 1823, and the revolutionary leaders were executed wholesale.

The next move was perfectly clear to any observer of political events. The Holy Alliance, with the scalps of Italian, Spanish and Portuguese revolutions at its belt, would forthwith crusade against freedom in Spanish America and Greece, and then would be in a position to attack directly the United States, which was 
the typical example of freedom from "legitimate" rulers. That the drive against Spanish America was coming is proved by a circular note of the Spanish minister of state to the Holy Alliance which was anticipated by President Monroe's message by just 24 days. In this circular the Count of Ofalia said:

The King, our sovereign, being restored to the throne of his ancestors in the enjoyment of his hereditary rights, has seriously turned his thoughts to the fate of his American dominions, distracted by civil war and brought to the brink of the most dangerous precipice....

These reflections powerfully animate-his Majesty to hope that the justice of his cause will meet with a firm support in the influence of the powers of Europe. Accordingly, the king has resolved upon inviting the cabinets of his dear and intimate allies to establish a conference at Paris, to the end that their plenipotentiaries, assembled there along with those of his Catholic Majesty, may aid Spain in adjusting the affairs of the revolted countries of America.... His Majesty, confiding in the sentiments of his allies, hopes that they will assist him in accomplishing the worthy object of upholding the principles of order and legitimacy, the subversion of which, once commenced in America, would presently communicate to Europe; and that they will aid him, at the same time, in re-establishing peace between this division of the globe and its colonies. ${ }^{19}$...

Great Britain, with George Canning as foreign minister, refused to participate in the French invasion of Spain. The instructions to the Duke of Wellington of September 27, 1822, before the Congress of Verona, said that "the uselessness and danger of any such intereference" in Spain were "so objectionable in principle" that the duke was "at once frankly and peremptorily to declare, that to any such interference, come what may, his Majesty will not be a party." The Duke of Wellington made a categorical statement to this effect on November 22, 1822, in reply to a French questionnaire. ${ }^{20}$

Canning received a copy of the Count of Ofalia's note of December 26, I823, to the Holy Alliance and replied to it on Jan-

${ }^{19}$ II British and Foreign State Papers, 55-57; Parliamentary Papers, 1824, XXIV.

${ }^{20}$ Io British and Foreign State Papers, 4-5, I I-I 2. 
uary 30, 1824. He then reviewed Great Britain's attitude toward the Spanish question, and in the course of his statement declared:

In a communication made, in the first instance to France, and afterward to other powers [Austria, Russia, Prussia, Portugal, the Netherlands, and the United States], as well as to Spain, the same opinions were repeated. ${ }^{21}$

The opinions referred to have become famous because they have been held by some to prove that the Monroe Doctrine was originated by Canning. The statement just quoted clearly indicates that Canning's well-known letter to Richard Rush, the American minister at London, was not an exclusive communication to the United States, and that as a consequence the British suggestions were not a special invitation to the United States to associate itself with an attitude assumed to make an appeal solely to the American Republic.

The principles declared by Canning in his letter to Rush of August 20, 1823, were:

I. We conceive the recovery of the colonies by Spain to be hopeless.

2. We conceive the question of the recognition of them, as independent states, to be one of time and circumstances.

3. We are, however, by no means disposed to throw any impediments in the way of an arrangement between them and the mother country by amicable negotiation.

4. We aim not at the possession of any portion of them ourselves.

5. We could not see any portion of them transferred to any other power with indifference.

If these feelings are, as I firmly believe them to be, common to your Government with ours, why should we hesitate mutually to confide them to each other, and to declare them in the face of the world? ${ }^{22}$

${ }^{21}$ II British and Foreign State Papers, 6I-62.

${ }^{22}$ John Bassett Moore, A Digest of International Law, VI, 389. 


\section{THE MONROE DOCTRINE.}

\section{President Monroe's Annual Message, December 2, $1823 .{ }^{23}$}

At the proposal of the Russian Imperial Government, made through the minister of the Emperor residing here, a full power and instructions have been transmitted to the minister of the United States at St. Petersburg, to arrange, by amicable negotiation, the respective rights and interests of the two nations on the northwest coast of this continent. A similar proposal has been made by his Imperial Majesty to the Government of Great Britain, which has likewise been acceded to. The Government of the United States has been desirous, by this friendly proceeding, of manifesting the great value which they have invariably attached to the friendship of the Emperor, and their solicitude to cultivate the best understanding with his Government. In the discussions to which this interest has given rise, and in the arrangements by which they may terminate, the occasion has been judged proper for asserting as a principle in which the rights and interests of the United States are involved, that the American continents, by the free and independent condition which they have assumed and maintain, are henceforth not to be considered as subjects for future colonization by any European powers. ${ }^{24}$ (Paragraph 7.)

It was stated at the commencement of the last session that a great effort was then making in Spain and Portugal to improve the condition of the people of those countries, and that it appeared to be conducted with extraordinary moderation. It need scarcely be remarked that the result has been, so far, very different from what was then anticipated. Of events in that quarter of the globe with which we have so much intercourse, and from which we derive our origin, we have always been anxious and interested spectators. The citizens of the United States cherish sentiments the most friendly in favor of the liberty and happiness of their fellow-men on that side of the Atlantic. In the wars of the European powers in matters relating to themselves we have never taken any part, nor does it comport with our policy so to do. It is only when our

${ }^{23}$ James Daniel Richardson, A Compilation of the Messages ard Papers of the Presidents, 778, 786-788.

${ }^{24} \mathrm{On}$ the Adams-Tuyll correspondence which preceded this declaration see Moore, Digest of International Law, VI, 397-399. 
rights are invaded or seriously menaced that we resent injuries or make preparation for our defense. With the movements in this hemisphere we are, of necessity, more immediately connected, and by causes which must be obvious to all enlightened and impartial observers. The political system of the allied powers is essentially different in this respect from that of America. This difference proceeds from that which exists in their respective Governments. And to the defense of our own, which has been achieved by the loss of so much blood and treasure, and matured by the wisdom of their most enlightened citizens, and under which we have enjoyed unexampled felicity, this whole nation is devoted. We owe it, therefore, to candor, and to the amicable relations existing between the United States and those powers, to declare that we should consider any attempt on their part to extend their system to any portion of this hemisphere as dangerous to our peace and safety. With the existing colonies or dependencies of any European power we have not interfered and shall not interfere. But with the Governments who have declared their independence, and maintained it, and whose independence we have, on great consideration and on just principles, acknowledged, we could not view any interposition for the purpose of oppressing them, or controlling in any other manner their destiny, by any European power, in any other light than as the manifestation of an unfriendly disposition toward the United States. In the war between these new Governments and Spain we declared our neutrality at the time of their recognition, and to this we have adhered and shall continue to adhere, provided no change shall occur which, in the judgment of the competent authorities of this Government, shall make a corresponding change on the part of the United States indispensable to their security. (Paragraph 48.)

The late events in Spain and Portugal show that Europe is still unsettled. Of this important fact no stronger proof can be adduced than that the allied powers should have thought it proper, on any principle satisfactory to themselves, to have interposed, by force, in the internal concerns of Spain. To what extent such interposition may be carried, on the same principle, is a question in which all independent powers whose Governments differ from theirs are interested, even those most remote, and surely none more so than the United States. Our policy in regard to Europe, which was adopted at an early stage of the wars which have so long agitated that quarter of the globe, nevertheless remains the same, which is, not to interfere in the internal concerns of any of its powers; to consider the Government de facto as the legitimate Government for us; to cultivate friendly relations with it, and to preserve those 
relations by a frank, firm and manly policy, meeting, in all instances, the just claims of every power; submitting to injuries from none. But in regard to these continents, circumstances are eminently and conspicuously different. It is impossible that the allied powers should extend their political system to any portion of either continent without endangering our peace and happiness; nor can any one believe that our Southern brethren, if left to themselves, would adopt it of their own accord. It is equally impossible, therefore, that we should behold such interposition, in any form, with indifference. If we look to the comparative strength and resources of Spain and those new Governments, and their distance from each other, it must be obvious that she can never subdue them. It is still the true policy of the United States to leave the parties to themselves, in the hope that other powers will pursue the same course. (Paragraph 49.)

\section{President Polk's Annual Message, December 2, $1845 .^{25}$}

It is well known to the American people and to all nations that this Government has never interfered with the relations subsisting between other governments. We have never made ourselves parties to their wars or their alliances; we have not sought their territories by conquest; we have not mingled with parties in their domestic struggles.... We may claim on this continent a like exemption from European interference. The nations of America are equally sovereign and independent with those of Europe. They possess the same rights, independent of all foreign interposition, to make war, to conclude peace, and to regulate their internal affairs. The people of the United States can not, therefore, view with indifference attempts of European powers to interfere

${ }^{25}$ Richardson, Messages and Papers of the Presidents, 2248-2249.

President Polk in a special message of April 29, 1848, further said:

"[The inhabitants of Yucatan] have, through their constituted authorities, implored the aid of this Government to save them from destruction [by an insurrection of Indians], offering in case this should be granted to transfer the 'dominion and sovereignty of the peninsula' to the United States. Similar appeals for aid and protection have been made to the Spanish and the English Governments.

"Whilst it is not my purpose to recommend the adoption of any measure with a view to the acquisition of the 'dominion and sovereignty' over Yucatan, yet, according to our established policy, we could not consent to a transfer of this 'dominion and sovereignty' either to Spain, Great Britain or any other European power." (Richardson, Messages and Papers, 243I-2432.) 
with the independent action of the nations on this continent. The American system of government is entirely different from that of Europe. ... We must ever maintain the principle that the people of this continent alone have the right to decide their own destiny. Should any portion of them, constituting an independent state, propose to unite themselves with our Confederacy, this will be a question for them and us to determine without any foreign interposition. We can never consent that European powers shall interfere to prevent such a union because it might disturb the "balance of power" which they may desire to maintain upon this continent. Near a quarter of a century ago the principle was distinctly announced to the world, in the annual message of one of my predecessors. ...

This principle will apply with greatly increased force should any European power attempt to establish any new colony in North America. In the existing circumstances of the world the present is deemed a proper occasion to reiterate and reaffirm the principle avowed by $\mathrm{Mr}$. Monroe and to state my cordial concurrence in its wisdom and sound policy. The reassertion of this principle, especially in reference to North America, is at this day but the promulgation of a policy which no European power should cherish the disposition to resist. Existing rights of every European nation should be respected, but it is due alike to our safety and our interests that the efficient protection of our laws should be extended over our whole territorial limits, and that it should be distinctly announced to the world as our settled policy that no future European colony or dominion shall with our consent be planted or established on any part of the North American continent.

\section{President Johnson's Annual Message, December 9, I868. ${ }^{26}$}

... While the United States have on all occasions professed a decided unwillingness that any part of this continent or of its adjacent islands shall be made a theater for a new establishment of monarchical power, too little has been done by us, on the other hand, to attach the communities by which we are surrounded to our own country, or to lend even a moral support to the efforts they are so resolutely and so constantly making to secure republican institutions for themselves....

Comprehensive national policy would seem to sanction the acquisition and incorporation into our Federal Union of the several adjacent

${ }^{26}$ Richardson, Messages and Papers of the Presidents, 3886-3887. 
continental and insular communities as speedily as it can be done peacefully, lawfully, and without any violation of national justice, faith or honor. Foreign possession or control of those communities has hitherto hindered the growth and impaired the influence of the United States....

... The conviction is rapidly gaining ground in the American mind that with the increased facilities for intercommunication between all portions of the earth the principles of free government, as embraced in our Constitution, if faithfully maintained and carried out, would prove of sufficient strength and breadth to comprehend within their sphere and influence the civilized nations of the world.

\section{President Grant's Messages.}

\section{a. First Annual Message, December 6, $1869 .^{27}$}

The United States have no disposition to interfere with the existing relations of Spain to her colonial possessions on this continent. ... These dependencies are no longer regarded as subject to transfer from one European power to another. When the present relations of colonies ceases, they are to become independent powers, exercising the right of choice and of self-control in the determination of their future condition and relations with other powers.

\section{b. Special Message, May 3 i, 1870 , on the Annexation of the Dominican Republic. ${ }^{23}$}

The doctrine promulgated by President Monroe has been adhered to by all political parties, and I now deem it proper to assert the equally important principle that hereafter no territory on this continent shall be regarded as subject of transfer to a European power.

\section{c. Special Message, June 13, 1870, on the Revolt in Cuba. ${ }^{29}$}

The strict adherence to this rule of public policy [admission of insurgency] has been one of the highest honors of American statesmanship, and has secured to this Government the confidence of the feeble powers on this continent, which induces them to rely upon its friendship and absence of designs of conquest and to look to the United States for

${ }^{27}$ Richardson, Messages and Papers of the Presidents, 3986.

${ }^{28}$ Richardson, Messages and Papers of the Presidents, 4015.

${ }^{20}$ Richardson, Messages and Papers of the Presidents, 4021. 
example and moral protection. It has given to this Government a position of prominence and of influence which it should not abdicate, but which imposes upon it the most delicate duties of right and of honor regarding American questions, whether those questions affect emancipated colonies or colonies still subject to European dominion.

\section{d. Special Message, April 5, i87i, on the Annexation of the Dominican Republic. ${ }^{30}$}

I believed ... that our institutions were broad enough to extend over the entire continent as rapidly as other peoples might desire to bring themselves under our protection. I believed further that we should not permit any independent government within the limits of North America to pass from a condition of independence to one of ownership or protection under a European power....

In view of the facts which had been laid before me, and with an earnest desire to maintain the "Monroe Doctrine," I believed that I would be derelict in my duty if I did not take measures to ascertain the exact wish of the Government and inhabitants of the Republic of San Domingo in regard to annexation and communicate the information to the people of the United States.

\section{President Hayes' Special Message, March 8, i880, Regard-} ING AN IsTHMIAN CANAL. ${ }^{31}$

The policy of this country is a canal under American control. The United States can not consent to the surrender of this control to any European power, or to any combination of European powers. If existing treaties between the United States and other nations, or if the rights of sovereignty or property of other nations stand in the way of this policy - a contingency which is not apprehended-suitable steps should be taken by just and liberal negotiations to promote and establish the American policy on this subject, consistently with the rights of the nations to be affected by it.

The capital invested by corporations or citizens of other countries in such an enterprise must, in a great degree, look for protection to one or

${ }^{30}$ Richardson, Messages and Papers of the Presidents, 4083.

${ }^{31}$ Richardson, Messages and Papers of the Presidents, 4537-4538. 
more of the great powers of the world. No European power can intervene for such protection without adopting measures on this continent which the United States would deem wholly inadmissible. If the protection of the United States is relied upon, the United States must exercise such control as will enable this country to protect its national interests and maintain the rights of those whose private capital is embarked in the work.

An interoceanic canal across the American Isthmus will essentially change the geographical relations between the Atlantic and Pacific coasts of the United States, and between the United States and the rest of the world. It will be the great ocean thoroughfare between our Atlantic and our Pacific shores, and virtually a part of the coast line of the United States. Our merely commercial interest in it is greater than that of all other countries, while its relations to our power and prosperity as a nation, to our means of defense, our unity, peace and safety are matters of paramount concern to the people of the United States. No other great power would, under similar circumstances, fail to assert a rightful control over a work so closely and vitally affecting its interest and welfare.

\section{President Harrison's Inaugural Address, March 4, I889."}

We have happily maintained a policy of avoiding all interference with European affairs. We have been only interested spectators of their contentions in diplomacy and in war, ready to use our friendly offices to promote peace, but never obtruding our advice and never attempting unfairly to coin the distresses of other powers into commercial advantage to ourselves. We have a just right to expect that our European policy will be the American policy of European courts.

It is so manifestly incompatible with those precautions for our peace and safety which all the great powers habitually observe and enforce in matters affecting them that a shorter waterway between our eastern and western seaboards should be dominated by any European Government that we may confidently expect that such a purpose will not be entertained by any friendly power.

${ }^{2}$ Richardson, Messages and Papers of the Presidents, 5445. 


\section{President Cleveland's Special Message, December 17, I895, Relative to the Venezuelan Boundary Dispute.}

Without attempting extended argument in reply to these positions, it may not be amiss to suggest that the doctrine upon which we stand is strong and sound, because its enforcement is important to our peace and safety as a nation and is essential to the integrity of our free institutions, and the tranquil maintenance of our distinctive form of government. It was intended to apply to every stage of our national life and can not become obsolete while our Republic endures....

If a European power by an extension of its boundaries takes possession of the territory of one of our neighboring Republics against its will and in derogation of its rights, it is difficult to see why to that extent such European power does not thereby attempt to extend its system of government to that portion of this continent which is thus taken. This is the precise action which President Monroe declared to be "dangerous to our peace and safety." ...

Practically the principle for which we contend has peculiar, if not exclusive, relation to the United States. It may not have been admitted in so many words to the code of international law, but since in international councils every nation is entitled to the rights belonging to it, if the enforcement of the Monroe Doctrine is something we may justly claim, it has its place in the code of international law as certainly and as securely as if it were specifically mentioned; and when the United States is a suitor before the high tribunal that administers international law the question to be determined is whether or not we present claims which the justice of that code of law can find to be right and valid.

The Monroe Doctrine finds its recognition in those principles of international law which are based upon the theory that every nation shall have its rights protected and its just claims enforced.

... The dispute has reached such a stage as to make it now incumbent upon the United States to take measures to determine with sufficient certainty for its justification what is the true divisional line between the Republic of Venezuela and British Guiana. The inquiry to that end should of course be conducted carefully and judicially.... When such report is made and accepted it will, in my opinion, be the duty of the United States to resist by every means in its power, as a wilful aggression upon its rights and interests, the appropriation by Great Britain

${ }^{33}$ Richardson, Messages and Papers of the Presidents, 6088-6090. 
of any lands or the exercise of governmental jurisdiction over any territory which after investigation we have determined of right belongs to Venezuela.

8. Reservation Made by the American Delegation to the Hague Convention for the Pacific Settlement of International Disputes, I 899 and $1907 .{ }^{34}$

Nothing contained in this convention shall be so construed as to require the United States of America to depart from its traditional policy of not entering upon, interfering with, or entangling itself in the political questions or internal administration of any foreign state; nor shall anything contained in the said convention be so construed as to require the relinquishment, by the United States of America, of its traditional attitude toward purely American questions.

A reservation of like purport was made to the general act of the international conference of Algeciras, signed April 7, 1906. (Foreign Relations of the United States, I906, r492.)

\section{Secretary of State Hay's Circular Note on the Open Door in China, I899.}

First. The recognition that no power will in any way interfere with any treaty port or any vested interest within any leased territory or within any so-called "sphere of interest" it may have in China.

Second. That the Chinese treaty tariff of the time being shall apply to all merchandise landed or shipped to all such ports as are within said "sphere of interest" (unless they be "free ports"), no matter to what nationality it may belong, and that duties so leviable shall be collected by the Chinese Government.

Third. That it will levy no higher harbor dues on vessels of another nationality frequenting any port in such "sphere" than shall be levied on vessels of its own nationality, and no higher railroad charges over lines built, controlled or operated within its "sphere" on merchandise belonging to citizens or subjects of other nationalities transported through

${ }^{24}$ William M. Malloy, Treaties, Conventions, etc., of the United States, 17761909, II, 2032.

${ }^{55} \mathrm{Mr}$. Hay to Mr. Tower, September 6, 1899 , Foreign Relations of the United States, 1899, 140-141. The same text with slight verbal changes was also sent to Germany, Great Britain, Italy and Japan. 
such "sphere" than shall be levied on similar merchandise belonging to its non-nationals transported over equal distances.

On March 20, 1900, Secretary Hay, in instructions to London, Paris, Berlin, St. Petersburg, Rome and Tokyo, wrote:

You will please inform the Government to which you are accredited that the conditions originally attached to its acceptance-that all other powers concerned should likewise accept the proposals of the United States-having been complied with, this Government will therefore consider the assent given to it by [France, Germany, Great Britain, Italy, Japan, Russia] as final and definitive. ${ }^{36}$

\section{IO. President Roosevelt's Messages.}

a. First Annual Message, December 3, igor. ${ }^{37}$

The Monroe Doctrine should be the cardinal feature of the foreign policy of all the nations of the two Americas, as it is of the United States. ... [The Monroe Doctrine] is a declaration that there must be no territorial aggrandizement by any non-American power at the expense of any American power on American soil. It is in no wise intended as hostile to any nation in the Old World. Still less is it intended to give cover to any aggression by one New World power at the expense of any other. It is simply a step, and a long step, toward assuring the universal peace of the world by securing the possibility of permanent peace on this hemisphere.

During the past century other influences have established the permanence and independence of the smaller states of Europe. Through the Monroe Doctrine we hope to be able to safeguard like independence and secure like permanence for the lesser among the New World nations.

This doctrine has nothing to do with the commercial relations of any American power, save that it in truth allows each of them to form such as it desires. In other words, it is really a guaranty of the commercial independence of the Americas. We do not ask under this doctrine for any exclusive commercial dealings with any other American state. We do not guarantee any state against punishment if it misconducts itself, provided that punishment does not take the form of the acquisition of territory by any non-American power.

${ }^{26}$ Foreign Relations of the United States, 1900, 142.

${ }^{27}$ Richardson, Messages and Papers of the Presidents, 6662-6663. 
Our attitude in Cuba is a sufficient guaranty of our own good faith. We have not the slightest desire to secure any territory at the expense of any of our neighbors. We wish to work with them hand in hand, so that all of us may be uplifted together, and we rejoice over the good fortune of any of them, we gladly hail their material prosperity and political stability, and are concerned and alarmed if any of them fall into industrial or political chaos. We do not wish to see any Old World military power grow up on this continent, or to be compelled to become a military power ourselves. The peoples of the Americas can prosper best if left to work out their own salvation in their own way.

\section{b. Second Annual Message, December 2, $1902 .^{38}$}

The Monroe Doctrine should be treated as the cardinal feature of American foreign policy; but it would be worse than idle to assert it unless we intended to back it up, and it can be backed up only by a thoroughly good navy. A good navy is not a provocative of war. It is the surest guaranty of peace.

\section{c. Fourth Annual Message, December 6, $1904{ }^{39}$}

It is not merely unwise, it is contemptible, for a nation, as for an individual, to use high-sounding language to proclaim its purposes, or to take positions which are ridiculous if unsupported by potential force, and then to refuse to provide this force. ...

It is our duty to remember that a nation has no more right to do injustice to another nation, strong or weak, than an individual has to do injustice to another individual; that the same moral law applies in one case as in the other. But we must also remember that it is as much the duty of the Nation to guard its own rights and its own interests as it is the duty of the individual so to do. ... .

It is not true that the United States feels any land hunger or entertains any projects as regards the other nations of the Western Hemisphere save such as are for their welfare. . . . If a nation shows that it knows how to act with reasonable efficiency and decency in social and political matters, if it keeps order and pays its obligations, it need fear no interference from the United States. Chronic wrongdoing, or an impotence which results in a general loosening of the ties of civilized society, may in

${ }^{28}$ Richardson, Messages and Papers of the Presidents, 6762.

Richardson, Messages and Papers of the Presidents, 705I-7054. 
America, as elsewhere, ultimately require intervention by some civilized nation, and in the Western Hemisphere the adherence of the United States to the Monroe Doctrine may force the United States, however reluctantly, in flagrant cases of such wrongdoing or impotence, to the exercise of an international police power....

We would interfere with them only in the last resort, and then only if it became evident that their inability or unwillingness to do justice at home and abroad had violated the rights of the United States or had invited foreign aggression to the detriment of the entire body of American nations.... .

In asserting the Monroe Doctrine, in taking such steps as we have taken in regard to Cuba, Venezuela and Panamá, and in endeavoring to circumscribe the theater of war in the Far East, and to secure the open door in China, we have acted in our own interest as well as in the interest of humanity at large. There are, however, cases in which, while our own interests are not greatly involved, strong appeal is made to our sympathies. ... In extreme cases action may be justifiable and proper. What form the action shall take must depend upon the circumstances of the case; that is, upon the degree of the atrocity and upon our power to remedy it. The cases in which we could interfere by force of arms as we interfered to put a stop to intolerable conditions in Cuba are necessarily very few....

\section{d. Fifth Annual Message, December 5, $1905.0^{40}$}

That our rights and interests are deeply concerned in the maintenance of the doctrine is so clear as hardly to need argument. This is especially true in view of the construction of the Panama Canal. As a mere matter of self-defense we must exercise a close watch over the approaches to this canal; and this means that we must be thoroughly alive to our interests in the Caribbean Sea.

There are certain essential points yhich must never be forgotten as regards the Monroe Doctrine. In the first place we must as a nation make it evident that we do not intend to treat it in any shape or way as an excuse for aggrandizement on our part at the expense of the republics to the south. We must recognize the fact that in some South American countries there has been much suspicion lest we should interpret the Monroe Doctrine as in some way inimical to their interests, and we must try to convince all the other nations of this continent once and for all

" Richardson, Messages and Papers of the Presidents, 7375. 
that no just and orderly government has anything to fear from us.... If all of the republics to the south of us will only grow as those to which I allude have already grown, all need for us to be the especial champions of the doctrine will disappear, for no stable and growing American Republic wishes to see some great non-American military power acquire territory in its neighborhood.

II. Substance of Notes Exchanged by Japan and the United States declaring their Policy in the Far East, November 30, 1908. ${ }^{41}$

I. It is the wish of the two Governments to encourage the free and peaceful development of their commerce on the Pacific Ocean.

2. The policy of both Governments, uninfluenced by any aggressive tendencies, is directed to the maintenance of the existing status quo in the region above mentioned and to the defense of the principle of equal opportunity for commerce and industry in China.

3. They are accordingly firmly resolved reciprocally to respect the territorial possessions belonging to each other in said region.

4. They are also determined to preserve the common interest of all powers in China by supporting by all pacific means at their disposal the independence and integrity of China and the principle of equal opportunity for commerce and industry of all nations in that Empire.

5. Should any event occur threatening the status quo as above described or the principle of equal opportunity as above defined, it remains for the two Governments to communicate with each other in order to arrive at an understanding as to what measures they may consider it useful to take.

\section{Senate Resolution, August 2, 1912."}

Resolved, That when any harbor or other place in the American continents is so situated that the occupation thereof for naval or military purposes might threaten the communications or the safety of the United States, the Government of the United States could not see without grave concern the possession of such harbor or other place by any corporation

${ }^{41}$ Malloy, Treaties, Conventions, etc., 1776-1909, I, 1045-1047.

- Congressional Record, Vol. 48. 10046-10047. The resolution was introduced July 31, 1912, by Mr. Lodge of Massachusetts as S. Res. 371 and was the subject of Senate Report 996 (ibid., 9923). The vote upon the text was 5 I yeas, 
or association which has such a relation to another Government, not American, as to give that Government practical power of control for naval or military purposes.

\section{I3. President Wilson's Special Address to the Senate, Jan- uary 22, i917, proposing the Monroe Doctrine as the Doctrine OF THE WORLD.}

Gentlemen of the Senate: On the eighteenth of December last I addressed an identic note to the governments of the nations now at war requesting them to state, more definitely than they had yet been stated by either group of belligerents, the terms upon which they would deem it possible to make peace. I spoke on behalf of humanity and of the rights of all neutral nations like our own, many of whose most vital interests the war puts in constant jeopardy. The Central Powers united in a reply which stated merely that they were ready to meet their antagonists in conference to discuss terms of peace. The Entente Powers have replied much more definitely and have stated, in general terms, indeed, but with sufficient definiteness to imply details, the arrangements, guarantees and

4 noes, 39 not voting. The Magdalena Bay incident, to which the resolution relates, was, by S. Res. 272, 62nd Cong., 2nd sess., the subject of a report by the Secretary of State (S. Doc. 640, ibid., 4170, and Cong. Docs., Vol. 6177).

Senator Lodge, on request, made a statement on the resolution just before its passage. He said:

"This resolution rests on a generally accepted principle of the law of nations, older than the Monroe doctrine. It rests on the principle that every nation has a right to protect its own safety, and that if it feels that the possession by a foreign power, for military or naval purposes, of any given harbor or place is prejudicial to its safety, it is its duty as well as its right to interfere. ...

"It has been made necessary by a change of modern conditions, under which, while a Government takes no action itself, the possession of an important place of the character I have described may be taken by a corporation or association which would be under the control of the foreign Government.

"The Monroe doctrine was, of course, an extension in our own interests of this underlying principle-the right of every nation to provide for its own safety. The Monroe doctrine, as we all know, was applied, so far as the taking possession of territory was concerned, to its being open to further colonization, and naturally did not touch upon the precise point involved here.

"The passage of this resolution has seemed to the committee, without division, I think, to be in the interest of peace. It is always desirable to make the position of a country in regard to a question of this kind known beforehand, and not to allow a situation to arise in which it might be necessary to urge a friendly power to withdraw when that withdrawal could not be made, perhaps, without some humiliation. The resolution is merely a statement of policy, allied to the Monroe doctrine, of course, but not necessarily dependent upon it or growing out of it." 
acts of reparation which they deem to be the indispensable conditions of a satisfactory settlement. We are that much nearer a definite discussion of the peace which shall end the present war. We are that much nearer the discussion of the international concert which must thereafter hold the world at peace. In every discussion of the peace that must end this war it is taken for granted that that peace must be followed by some definite concert of power which will make it virtually impossible that any such catastrophe should ever overwhelm us again. Every lover of mankind, every sane and thoughtful man must take that for granted.

I have sought this opportunity to address you because I thought that I owed it to you, as the council associated with me in the final determination of our international obligations, to disclose to you without reserve the thought and purpose that have been taking form in my mind in regard to the duty of our Government in the days to come when it will be necessary to lay afresh and upon a new plan the foundations of peace among the nations.

It is inconceivable that the people of the United States should play no part in that great enterprise. To take part in such a service will be the opportunity for which they have sought to prepare themselves by the very principles and purposes of their polity and the approved practices of their Government ever since the days when they set up a new nation in the high and honorable hope that it might in all that it was and did show mankind the way to liberty. They cannot in honor withhold the service to which they are now about to be challenged. They do not wish to withhold it. But they owe it to themselves and to the other nations of the world to state the conditions under which they will feel free to render it.

That service is nothing less than this, to add their authority and their power to the authority and force of other nations to guarantee peace and justice throughout the world. Such a settlement cannot now be long postponed. It is right that before it comes this Government should frankly formulate the conditions upon which it would feel justified in asking our people to approve its formal and solemn adherence to a League for Peace. I am here to attempt to state those conditions.

The present war must first be ended; but we owe it to candor and to a just regard for the opinion of mankind to say that, so far as our participation in guarantees of future peace is concerned, it makes a great deal of difference in what way and upon what terms it is ended. The treaties and agreements which bring it to an end must embody terms which will create a peace that is worth guaranteeing and preserving, a peace that 
will win the approval of mankind, not merely a peace that will serve the several interests and immediate aims of the nations engaged. We shall have no voice in determining what those terms shall be, but we shall, I feel sure, have a voice in determining whether they shall be made lasting or not by the guarantees of a universal covenant; and our judgment upon what is fundamental and essential as a condition precedent to permanency should be spoken now, not afterwards when it may be too late.

No covenant of co-operative peace that does not include the peoples of the New World can suffice to keep the future safe against war; and yet there is only one sort of peace that the peoples of America could join in guaranteeing. The elements of that peace must be elements that engage the confidence and satisfy the principles of the American governments, elements consistent with their political faith and with the practical convictions which the peoples of America have once for all embraced and undertaken to defend.

I do not mean to say that any American government would throw any obstacle in the way of any terms of peace the governments now at war might agree upon, or seek to upset them when made, whatever they might be. I only take it for granted that mere terms of peace between the belligerents will not satisfy even the belligerents themselves. Mere agreements may not make peace secure. It will be absolutely necessary that a force be created as a guarantor of the permanency of the settlement so much greater than the force of any nation now engaged or any alliance hitherto formed or projected that no nation, no probable combination of nations could face or withstand it. If the peace presently to be made is to endure, it must be a peace made secure by the organized major force of mankind.

The terms of the immediate peace agreed upon will determine whether it is a peace for which such a guarantee can be secured. The question upon which the whole future peace and policy of the world depends is this: Is the present war a struggle for a just and secure peace, or only for a new balance of power? If it be only a struggle for a new balance of power, who will guarantee, who can guarantee, the stable equilibrium of the new arrangement? Only a tranquil Europe can be a stable Europe. There must be, not a balance of power, but a community of power; not organized rivalries, but an organized common peace.

Fortunately we have received very explicit assurances on this point. The statesmen of both of the groups of nations now arrayed against one another have said, in terms that could not be misinterpreted, that it was no part of the purpose they had in mind to crush their antagonists. But 
the implications of these assurances may not be equally clear to all,may not be the same on both sides of the water. I think it will be serviceable if $I$ attempt to set forth what we understand them to be.

They imply, first of all, that it must be a peace without victory. It is not pleasant to say this. I beg that I may be permitted to put my own interpretation upon it and that it may be understood that no other interpretation was in my thought. I am seeking only to face realities and to face them without soft concealments. Victory would mean peace forced upon the loser, a victor's terms imposed upon the vanquished. It would be accepted in humiliation, under duress, at an intolerable sacrifice, and would leave a sting, a resentment, a bitter memory upon which terms of peace would rest, not permanently, but only as upon quicksand. Only a peace between equals can last. Only a peace the very principle of which is equality and a common participation in a common benefit. The right state of mind, the right feeling between nations, is as necessary for a lasting peace as is the just settlement of vexed questions of territory or of racial and national allegiance.

The equality of nations upon which peace must be founded if it is to last must be an equality of rights; the guarantees exchanged must neither recognize nor imply a difference between big nations and small, between those that are powerful and those that are weak. Right must be based upon the common strength, not upon the individual strength, of the nations upon whose concert peace will depend. Equality of territory or of resources there of course cannot be; nor any other sort of equality not gained in the ordinary peaceful and legitimate development of the people themselves. But no one asks or expects anything more than an equality of rights. Mankind is looking now for freedom of life, not for equipoises of power.

And there is a deeper thing involved than even equality of right among organized nations. No peace can last, or ought to last, which does not recognize and accept the principle that governments derive all their just powers from the consent of the governed, and that no right anywhere exists to hand peoples about from sovereignty to sovereignty as if they were property. I take it for granted, for instance, if I may venture upon a single example, that statesmen everywhere are agreed that there should be a united, independent and autonomous Poland, and that henceforth inviolable security of life, of worship, and of industrial and social development should be guaranteed to all peoples who have lived hitherto under the power of governments devoted to a faith and purpose hostile to their own. 
I speak of this, not because of any desire to exalt an abstract political principle which has always been held very dear by those who have sought to build up liberty in America, but for the same reason that I have spoken of the other conditions of peace which seem to me clearly indispensable,because I wish frankly to uncover realities. Any peace which does not recognize and accept this principle will inevitably be upset. It will not rest upon the affections or the convictions of mankind. The ferment of spirit of whole populations will fight subtly and constantly against it, and all the world will sympathize. The world can be at peace only if its life is stable, and there can be no stability where the will is in rebellion, where there is not tranquillity of spirit and a sense of justice, of freedom and of right.

So far as practicable, moreover, every great people now struggling towards a full development of its resources and of its powers should be assured a direct outlet to the great highways of the sea. Where this cannot be done by the cession of territory, it can no doubt be done by the neutralization of direct rights of way under the general guarantee which will assure the peace itself. With a right comity of arrangement no nation need be shut away from free access to the open paths of the world's commerce.

And the paths of the sea must alike in law and in fact be free. The freedom of the seas is the sine qua non of peace, equality and co-operation. No doubt a somewhat radical reconsideration of many of the rules of international practice hitherto thought to be established may be necessary in order to make the seas indeed free and common in practically all circumstances for the use of mankind, but the motive for such changes is convincing and compelling. There can be no trust or intimacy between the peoples of the world without them. The free, constant, unthreatened intercourse of nations is an essential part of the process of peace and of development. It need not be difficult either to define or to secure the freedom of the seas if the governments of the world sincerely desire to come to an agreement concerning it.

It is a problem closely connected with the limitation of naval armaments and the co-operation of the navies of the world in keeping the seas at once free and safe. And the question of limiting naval armaments opens the wider and perhaps more difficult question of the limitation of armies and of all programs of military preparation. Difficult and delicate as these questions are, they must be faced with the utmost candor and decided in a spirit of real accommodation if peace is to come with healing in its wings, and come to stay. Peace cannot be had without concession 
and sacrifice. There can be no sense of safety and equality among the nations if great preponderating armaments are henceforth to continue here and there to be built up and maintained. The statesmen of the world must plan for peace and nations must adjust and accommodate their policy to it as they have planned for war and made ready for pitiless contest and rivalry. The question of armaments, whether on land or sea, is the most immediately and intensely practical question connected with the future fortunes of nations and of mankind.

I have spoken upon these great matters without reserve and with the utmost explicitness because it has seemed to me to be necessary if the world's yearning desire for peace was anywhere to find free voice and utterance. Perhaps I am the only person in high authority amongst all the peoples of the world who is at liberty to speak and hold nothing back. I am speaking as an individual, and yet I am speaking also, of course, as the responsible head of a great Government, and I feel confident that I have said what the people of the United States would wish me to say. May I not add that I hope and believe that I am in effect speaking for liberals and friends of humanity in every nation and of every program of liberty? I would fain believe that I am speaking for the silent mass of mankind everywhere who have as yet had no place or opportunity to speak their real hearts out concerning the death and ruin they see to have come already upon the persons and the homes they hold most dear.

And in holding out the expectation that the people and Government of the United States will join the other civilized nations of the world in guaranteeing the permanence of peace upon such terms as I have named I speak with the greater boldness and confidence because it is clear to every man who can think that there is in this promise no breach in either our traditions or our policy as a nation, but a fulfilment, rather, of all that we have professed or striven for.

I am proposing, as it were, that the nations should with one accord adopt the doctrine of President Monroe as the doctrine of the world: that no nation should seek to extend its polity over any other nation or people, but that every people should be left free to determine its own polity, its own way of development, unhindered, unthreatened, unafraid, the little along with the great and powerful.

I am proposing that all nations henceforth avoid entangling alliances which would draw them into competitions of power, catch them in a net of intrigue and selfish rivalry, and disturb their own affairs with influences intruded from without. There is no entangling alliance in a concert of power. When all unite to act in the same sense and with the same 
purpose all act in the common interest and are free to live their own lives under a common protection.

I am proposing government by the consent of the governed; that freedom of the seas which in international conference after conference representatives of the United States have urged with the eloquence of those who are the convinced disciples of liberty; and that moderation of armaments which makes of armies and navies a power for order merely, not an instrument of aggression or of selfish violence.

These are American principles, American policies. We could stand for no others. And they are also the principles and policies of forward looking men and women everywhere, of every modern nation, of every enlightened community. They are the principles of mankind and must prevail. 






\section{HOME USE CIRCULATION DEPARTMENT MAIN LIBRARY}

This book is due on the last date stamped below. 1-month loans may be renewed by calling 642-3405. 6 -month loans may be recharged by bringing books to Circulation Desk.

Renewals and recharges may be made 4 days prior to due date.

ALL BOOKS ARE SUBJECT TO RECALL 7 DAYS AFTER DATE CHECKED OUT.

APR 11987639 SEP 011995

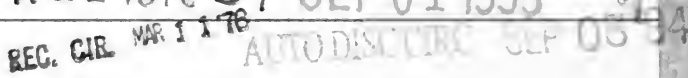

MAY 1197789

REC. CIR,APR 1177 JAN 172007

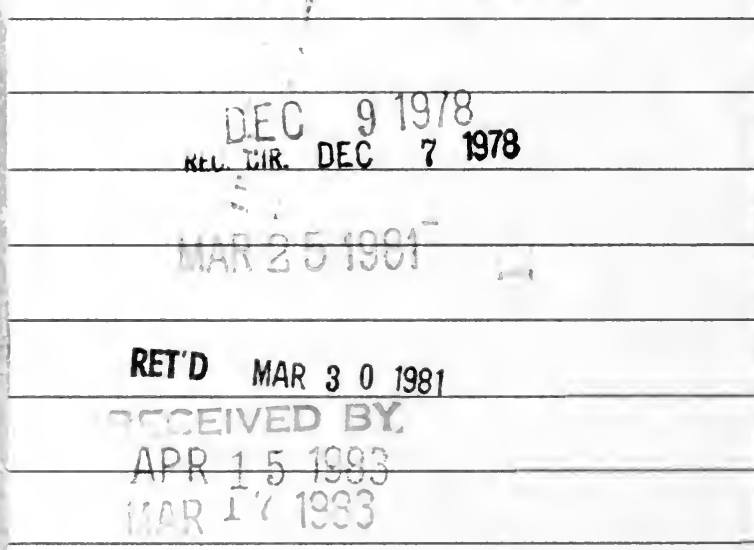

CIKCCLLATION DEOT,

LD2 $1-\mathrm{A}-40 m-8,75$

(S7737L)
General Library

University of California

Berkeley 


\section{GENERAL LIBRARY - U.C. BERKELEY}

$6+2+2$
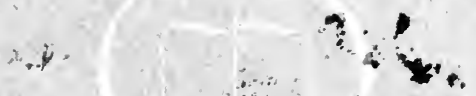

at

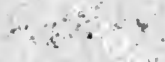

$\rightarrow x \rightarrow x_{i n}$ 
